\title{
Informal Urban Green Space: Residents' Perception, Use, and Management Preferences across Four Major Japanese Shrinking Cities
}

\author{
Christoph D. D. Rupprecht \\ FEAST Project, Research Institute for Humanity and Nature, Kyoto 6038047, Japan; crupprecht@chikyu.ac.jp; \\ Tel.: +81-75-707-2499
}

Received: 3 August 2017; Accepted: 22 August 2017; Published: 25 August 2017

\begin{abstract}
Urban residents' health depends on green infrastructure to cope with climate change. Shrinking cities could utilize vacant land to provide more green space, but declining tax revenues preclude new park development-a situation pronounced in Japan, where some cities are projected to shrink by over ten percent, but lack green space. Could informal urban green spaces (IGS; vacant lots, street verges, brownfields etc.) supplement parks in shrinking cities? This study analyzes residents' perception, use, and management preferences (management goals, approaches to participatory management, willingness to participate) for IGS using a large, representative online survey $(n=1000)$ across four major shrinking Japanese cities: Sapporo, Nagano, Kyoto and Kitakyushu. Results show that residents saw IGS as a common element of the urban landscape and their daily lives, but their evaluation was mixed. Recreation and urban agriculture were preferred to redevelopment and non-management. For participative management, residents saw a need for the city administration to mediate usage and liability, and expected an improved appearance, but emphasized the need for financial and non-financial support. A small but significant minority $(\sim 10 \%)$ were willing to participate in management activities. On this basis, eight principles for participatory informal green space planning are proposed.
\end{abstract}

Keywords: vacant land; land use; urban planning; Japan; wasteland; green infrastructure; recreation; landscape; participatory management; depopulation

\section{Introduction}

Urban green spaces as an essential element of green infrastructure are increasingly linked to human wellbeing [1-5]. However, the benefits they provide come at a price, from maintenance of facilities and vegetation to day-to-day management [6]. This financial burden is particularly pronounced in countries such as Japan, where municipalities face a shrinking tax base due to demographic trends of aging and depopulation [7]. Furthermore, maintenance costs for urban green spaces in Japan are rising, as parks created during the 1960s and 1970s period of economic and population growth are increasingly in need of refurbishment [8]. On the other hand, Japanese cities provide residents only with a comparatively low amount of green space (ca. $10 \mathrm{~m}^{2}$ per person in major cities [9]). This raises the question of how local governments can procure additional green space areas, not least to adapt to climate change, rising temperatures and associated heat waves. Cities in North America and Europe have been looking toward participative vacant land management to meet residents' needs [10-14]. However, despite introducing participative management for formal green spaces since the 1990s [15], local governments in Japan have been slow to explore this direction for non-traditional green spaces. Yet such schemes might create more recreational green space, provide benefits associated with green infrastructure, and could simultaneously alleviate the costs of maintenance. One reason for the lack of similar initiatives in Japan may lie in the scarcity of related 
research—we still know little about what residents in Japan think of informal urban green spaces such as vacant lots, street verges or brownfields, let alone participative management approaches. To fill this gap, this paper seeks to provide some insight by analyzing how residents in four major shrinking Japanese cities perceive and use informal urban green spaces, what management goals and approaches they prefer, and how willing they are to participate in managing such spaces.

Japanese cities are facing a major demographic challenge with consequences for urban land and green space management. This makes the country a useful object of study, because similar demographic trends are expected in other countries such as South Korea or China as the population peaks and the economy enters the post-growth stage. Until 2040, many are projected to experience both rapid aging and population decline, with some likely to lose over $10 \%$ of their total population [16]. The major effects of this trend are fourfold. First, the cumulative effects of aging and depopulation are eroding cities' tax base, which in turn forces them to balance expenses for maintaining green spaces with competing demands such as aging water infrastructure. This puts budgets for green space under scrutiny and leaves them at risk of being cut, even though many Japanese cities already fail to provide the $10 \mathrm{~m}^{2}$ of park area per person set in governmental standards [17]. Second, the number of both vacant houses and vacant lots are increasing [18], a trend that will likely accelerate as population decline intensifies. While this process could be seen as an opportunity for municipalities to buy land at a moderate price to increase public green space, their financial situation makes this difficult. In fact, strategic park planning in Japan has recently focused on protecting current levels of green space rather than expanding them, as cities are struggling to cover maintenance costs for parks built during the decades of high population and economic growth. Third, as the population demographics change, so do people's green space and nature needs [19]. Recent years have seen a strong demand for recreational urban agriculture, with long waiting lists for community garden parcels being a common occurrence. While some cities such as Yokohama have started retrofitting parks with areas for growing vegetables, such initiatives are still rare. Finally, Japanese cities will need to invest heavily into green infrastructure to adapt to and mitigate the effects of rising global temperatures due to climate change [20-22]. The cities' aging population is particular at risk from heat-related health problems, making this also an urgent issue of public health. These demographic transition-related major effects have led researchers to investigate the potential of non-traditional green spaces [23].

Recent research has shown that both in Japan and abroad, informal urban green spaces (IGS) such as vacant lots, street verges, brownfields, power line corridors and waterside spaces can make up about $5 \%$ of urban land [24]. Moreover, residents are already using these spaces for recreation, both as adults and children $[23,25]$. However, not all residents evaluate these spaces favorably as they are largely unmanaged. In particular, the aesthetics of wild nature do not necessarily directly translate from a Western to a Japanese cultural context [26], where many residents prefer to see a human touch as evidence of human care and attention for a space. Against an international background of residents using and re-using-often spontaneously-land considered derelict or unwanted by conventional urban planning [27-29], researchers have thus called for exploring ways informal green spaces in shrinking Japanese cities could be managed by the local community using participatory approaches [23]. However, a number of questions about participatory IGS management in Japan remain unanswered. Addressing the following gaps in the literature will support municipalities in planning and implementing such management approaches, with the intention of contributing to residents' wellbeing.

Under what circumstances and in what form might participatory IGS management be feasible in shrinking Japanese cities? To answer these questions, two major gaps in the existing literature need to be addressed. First, existing exploratory studies $[23,25]$ on how residents in Japan perceive, use, and evaluate IGS have been limited in scope (single city) and sample size $(<200)$, were not representative and, as mail-back surveys, may have suffered from bias where only residents interested in the topic responded. Second, we know little about how residents think of participatory IGS management, from their preferred management goals and approaches to acceptable levels and forms of participation. 
This paper thus focuses on the following questions: (1) how do residents perceive, use and evaluate IGS across major shrinking Japanese cities; (2) what management goals do residents prefer for IGS; (3) how do residents think about different ways, approaches and circumstances in participatory IGS management; and (4) how willing are residents to engage in participatory IGS management? Addressing these questions is important, because the resulting findings and insights may inform urban planning, climate adaptation and participatory management in post-growth industrialized countries, using Japan as a case where depopulation is most advanced. The study thus contributes to the local (site-specific), national and international discourse.

\section{Materials and Methods}

\subsection{Study Sites}

This study focused on the Japanese cities Sapporo, Kyoto, Kitakyushu and Nagano, all four projected to lose over $10 \%$ of their current population until 2040 [16]. They were selected to represent the regional Japanese cities expected to shrink most severely as a result of Japan's projected national population decline. Differences in city age, population size, population density and green space per capita (Table 1) and geographic location (Figure 1) provide a range variety of geographic context. Additionally, including Sapporo allows comparison of results with previous research on IGS in the city, in particular addressing potential nonresponse bias in the previous mail-back survey.
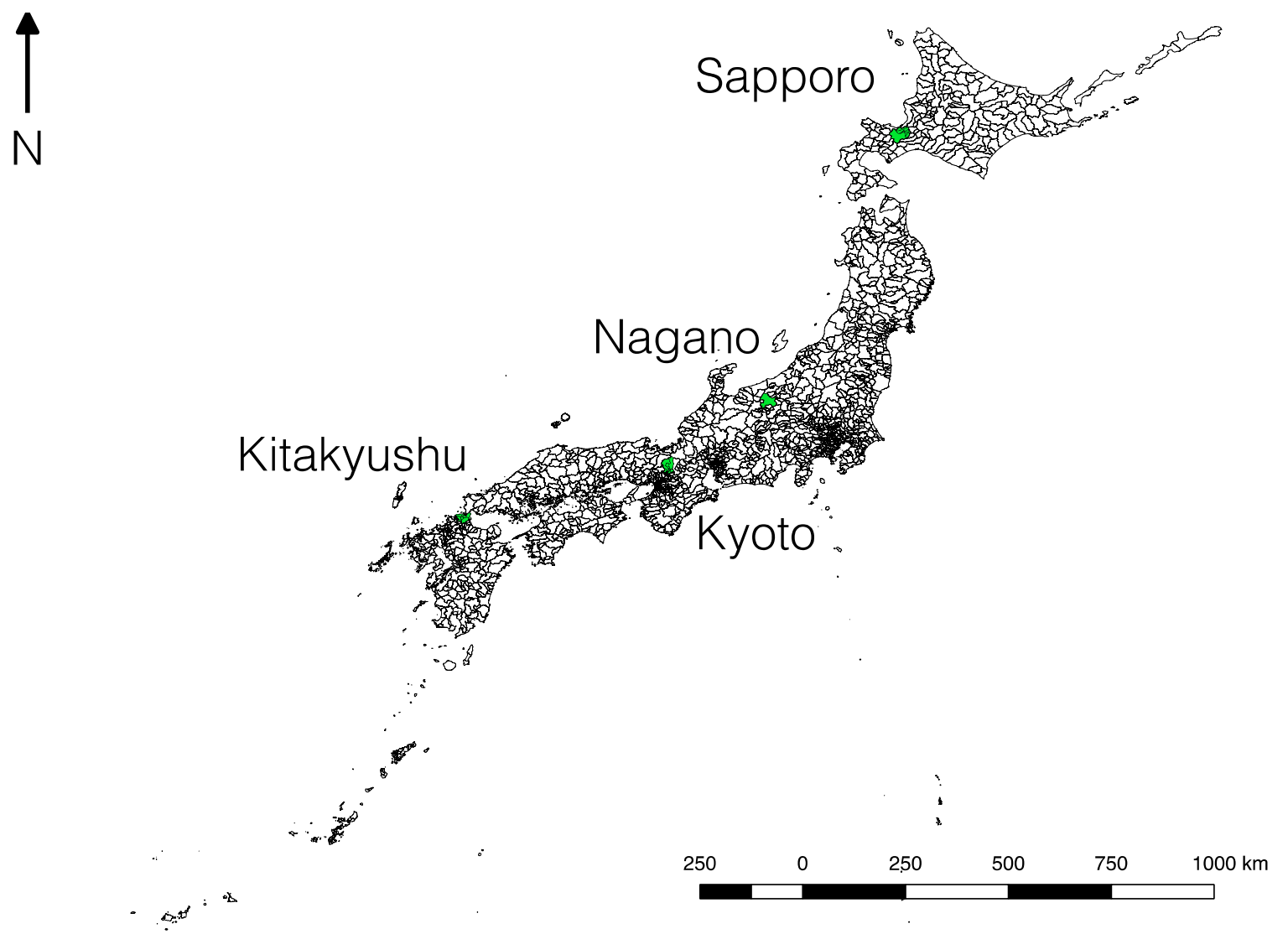

Figure 1. Location of the four targeted shrinking cities in Japan (green). 
Table 1. Comparison of study sites.

\begin{tabular}{|c|c|c|c|c|}
\hline Characteristics & Sapporo & Kyoto & Kitakyushu & Nagano \\
\hline City status & $\begin{array}{c}1902 \\
\text { (founded 1824) }\end{array}$ & $\begin{array}{l}1889 \text { (founded } \\
\sim 600 \mathrm{AD} \text { ) }\end{array}$ & $\begin{array}{l}1963 \text { (formerly Mojigaseki, } \\
\text { founded } \sim 645 \text { AD) }\end{array}$ & $\begin{array}{l}1897 \text { (founded } \\
\sim 642 \mathrm{AD} \text { ) }\end{array}$ \\
\hline Population (2015) & 1.95 million & 1.48 million & 961,000 & 378,000 \\
\hline Projected population (2040) & 1.71 million & 1.28 million & 784,000 & 302,000 \\
\hline Area $\left(\mathrm{km}^{2}\right)$ & 1121 & 828 & 492 & 835 \\
\hline $\begin{array}{l}\text { Population density } \\
\text { (inhabitants } / \mathrm{km}^{2} \text { ) }\end{array}$ & 1741 & 1782 & 1954 & 452 \\
\hline Climate (Köppen-Geiger) & Dfa & $\mathrm{Cfa}$ & $\mathrm{Cfa}$ & Cfa \\
\hline Green space per capita (2015) & 12.5 & 4.4 & 12.0 & 9.4 \\
\hline
\end{tabular}

\subsection{Data Collection, Survey Instrument and Data Analysis}

The survey was conducted across the four study sites through an online survey coordinated through Rakuten Research, a major Japanese online polling service. Respondents were recruited from the service's panel, consented to and received compensation for their participation in accordance to the service's policies (the exact compensation is not disclosed by the company, but is less than $¥ 1000 /$ US $\$ 10 / 10 €$ ). Responses were collected over a period of two weeks in late 2016, and sampled to be representative for the population demographic of the respective cities. The study was approved by the home institution's research ethics committee (RIHN2017-1).

The survey instrument (see File S1) consisted of 24 questions in four parts: (1) respondents' perception, recreational use and evaluation of IGS; (2) respondents' preferences for IGS management goals, management approaches, and willingness to participate in management; (3) respondents' opinion about the value of urban nature and general preferences for urban land use directions in shrinking cities; and (4) respondents' socio-demographic data. Question types included multiple choice, Likert-scale, modified Likert-scale (agree with option A or B) and open comment questions. The cover page of the survey instrument contained a brief explanation of what IGS are alongside a typology with color photographs (Figure 2; File S1). Native Japanese speakers helped to ensure the survey instrument was linguistically correct and easy to read. Questions in part one drew on previous research about residents' perception, use and evaluation of IGS in Sapporo and Brisbane [23] and used a modified version of this study's survey instrument [30]. Multiple-choice questions were replaced by Likert scales to improve measurement precision. Questions in part two address calls in the literature to explore participative IGS and urban green space management approaches [23,25].

Choices for management goals ranged from urban greening, recreation and conservation to redevelopment, parking space (a common use for vacant land in Japan) and an option to forgo management altogether. Regarding management approaches, questions sought to clarify who respondents believe is responsible for managing IGS, whether existing green space management approaches are appropriate for IGS, what participatory IGS management would mean for its aesthetics and issues such as liability, whether use could be temporary, and what degree of support (financial, training) residents-as-managers would require from authorities. Willingness to participate in IGS management was tested using questions adopted from recent Japanese research on volunteers' willingness to work in participatory green space conservation [31]. Questions covered willingness to contribute time or money, participation frequency, willingness to assume a leadership role, and a variety of participatory activities. Questions in part three consisted of a modified NEP scale developed for prior research on IGS [23], while also asking respondents what strategic planning goals they preferred for shrinking cities (growth, larger housing, more recreational green space, more urban agriculture, or returning space to nature). These questions were intended to create a larger normative background against which more concrete, local scale IGS management goals and approaches can be 
discussed. Finally, questions in part four asked for respondents' socio-demographic data, including type of housing and residential green space, length of local residency, level of educational attainment, yearly income and post code.

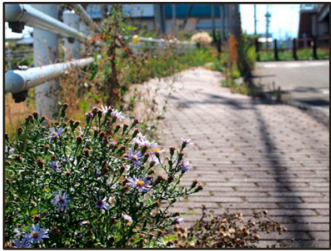

Street verges

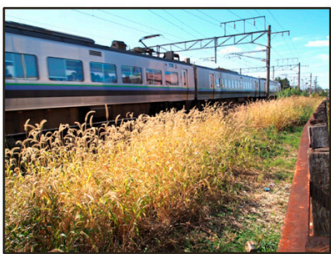

Railway verges

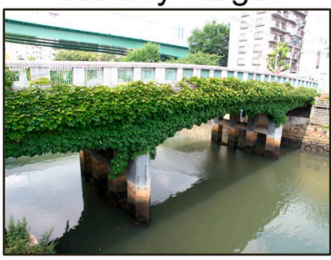

Overgrown structures

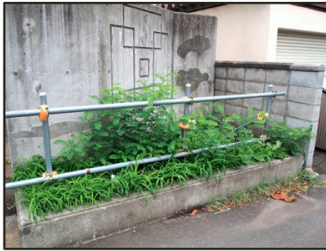

Gap spaces

Informal green space

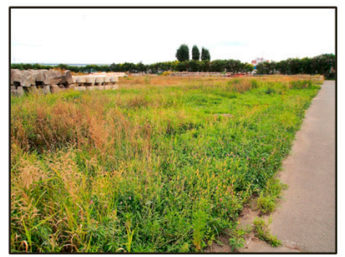

Brownfields

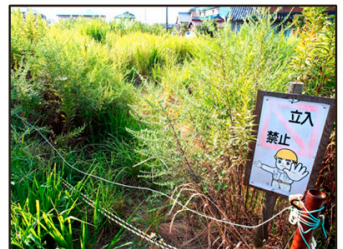

Vacant lots

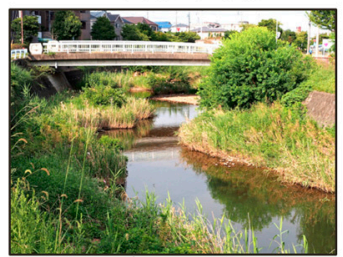

River/canal banks

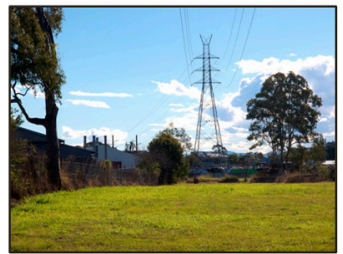

Powerlines

Figure 2. Typology of IGS (translated to English) with example photographs of different IGS types, as shown to respondents in the online survey. From top left, clockwise: street verge, gap, vacant lot, waterside, power-line corridor, brownfield, structural IGS, railway verge.

Data was analyzed using descriptive and inferential statistics following procedures described by Field and colleagues [32] using R [33] and its packages likert [34] and FactoMineR [35] as well as JASP [36] and jamovi [37]. The map of study locations (Figure 1) was created with QGIS [38], but no spatial analysis was performed for this study. The analyzed data set is available as supplementary material. Multiple correspondence analysis was used to explore the multivariate relationship of key IGS and demographic variables. Non-parametric tests (chi-square, Wilcoxon rank-sum, Kruskal-Wallis, Spearman) were used as analysis indicated data did not fulfill the assumptions of parametric tests (normal distribution, homogeneity). Post-hoc corrections for pairwise comparisons with the Kruskal-Wallis test were performed using the Dwass-Steel-Critchlow-Fligner test to identify significant differences between individual pairs, which are reported in the text using abbreviated study location pairs (e.g., Sapporo-Nagano (SP-NA), Kyoto-Kitakyushu (KY-KK)). The reliability of core scales (IGS benefits, IGS problems, management goals, management styles, willingness to participate) was adequate or better (Cronbach's alpha $>0.7$ ). The analyzed data set is available as supplementary material (File S2).

\section{Results}

\subsection{Sample Characteristics}

A representative sample for the population demographic of the respective cities with a total of 1000 valid responses was collected (see Table 2). Income and length of residency did not differ significantly between cities. Level of educational attainment differed significantly $\left(X^{2}(12)=23.93\right.$, $p<0.05)$, with Kyoto (71\%) having the most and Kitakyushu (57\%) the least respondents with a university or post-graduate degree. Housing also differed significantly $\left(X^{2}(12)=149.0, p<0.001\right)$. 
In Nagano, most respondents were living in a house with garden (67\%), while in Sapporo most were living in an apartment without shared green space (46\%). In Kyoto, a quarter of respondents $(24 \%)$ lived in a house without garden, whereas in all other cities less than $10 \%$ of respondents did. Respondents had been living in their respective city for 20 years on average (range 0-69), with no significant difference between cities.

Table 2. Demographic characteristics of respondents $(n=1000)$.

\begin{tabular}{|c|c|c|}
\hline Age & Mean/SD/Lowest/Highest & $46 / 13 / 20 / 69$ \\
\hline & Respondents in their $20 \mathrm{~s}$ & $16 \%$ \\
\hline & Respondents in their 30s & $19 \%$ \\
\hline & Respondents in their $40 \mathrm{~s}$ & $23 \%$ \\
\hline & Respondents in their 50s & $20 \%$ \\
\hline & Respondents in their $60 \mathrm{~s}$ & $22 \%$ \\
\hline \multirow{2}{*}{ Sex } & Female & $50 \%$ \\
\hline & Male & $50 \%$ \\
\hline \multirow{5}{*}{ Education (highest attained) } & Junior high school & $2 \%$ \\
\hline & High school & $31 \%$ \\
\hline & University & $57 \%$ \\
\hline & Postgraduate & $7 \%$ \\
\hline & Other & $4 \%$ \\
\hline \multirow{5}{*}{ Housing } & Detached with garden & $43 \%$ \\
\hline & Detached without garden & $10 \%$ \\
\hline & Apartment, shared green space & $12 \%$ \\
\hline & $\begin{array}{l}\text { Apartment, no shared green } \\
\text { space }\end{array}$ & $33 \%$ \\
\hline & Other & $1 \%$ \\
\hline \multirow{8}{*}{ Income } & Under $¥ 2$ million & $10 \%$ \\
\hline & $¥ 2-4$ million & $24 \%$ \\
\hline & $¥ 400-600$ million & $19 \%$ \\
\hline & $¥ 600-800$ million & $13 \%$ \\
\hline & $¥ 800-1000$ million & $9 \%$ \\
\hline & $¥ 1000-1250$ million & $4 \%$ \\
\hline & Over $¥ 1250$ million & $3 \%$ \\
\hline & $\begin{array}{c}\text { Don't know / Don't want to } \\
\text { answer }\end{array}$ & $19 \%$ \\
\hline
\end{tabular}

Asked about their attitude towards urban nature, respondents highly valued urban nature (Figure 3), with no significant differences between cities or respondent sex. With increasing age, respondents valued green space in their neighborhood more (Figure 3, Q3; $p<0.05, r_{s}=-0.07$; the negative effect size results from the coding of agreement (low) to disagreement (high)), were more likely to agree nature has intrinsic value (Figure 3, Q2; $p<0.05, r_{s}=-0.06$ ), and were more willing to donate (Figure 3, Q1, $p<0.05, r_{s}=-0.06$ ). Asked about their opinion on how to proceed when cities shrink, respondents preferred converting the land to green space (for recreation or agriculture) over increased housing size or growth at all cost (Figure 4). The only significant difference between the four cities was respondents' support for urban agriculture (Figure 4, Q5; $\mathrm{H}(3)=8.30, p<0.05$; significant pairwise differences: Sapporo-Nagano (SP-NA), $p=0.005$ ). Sex had no effect on opinion about shrinking cities. In contrast to their attitude towards urban nature, with rising age respondents were less likely to support using space in shrinking cities to increase green space (Figure $4, Q 4 ; p<0.001$, $\left.r_{s}=0.11\right)$. 
Please tell us how you think about urban nature.

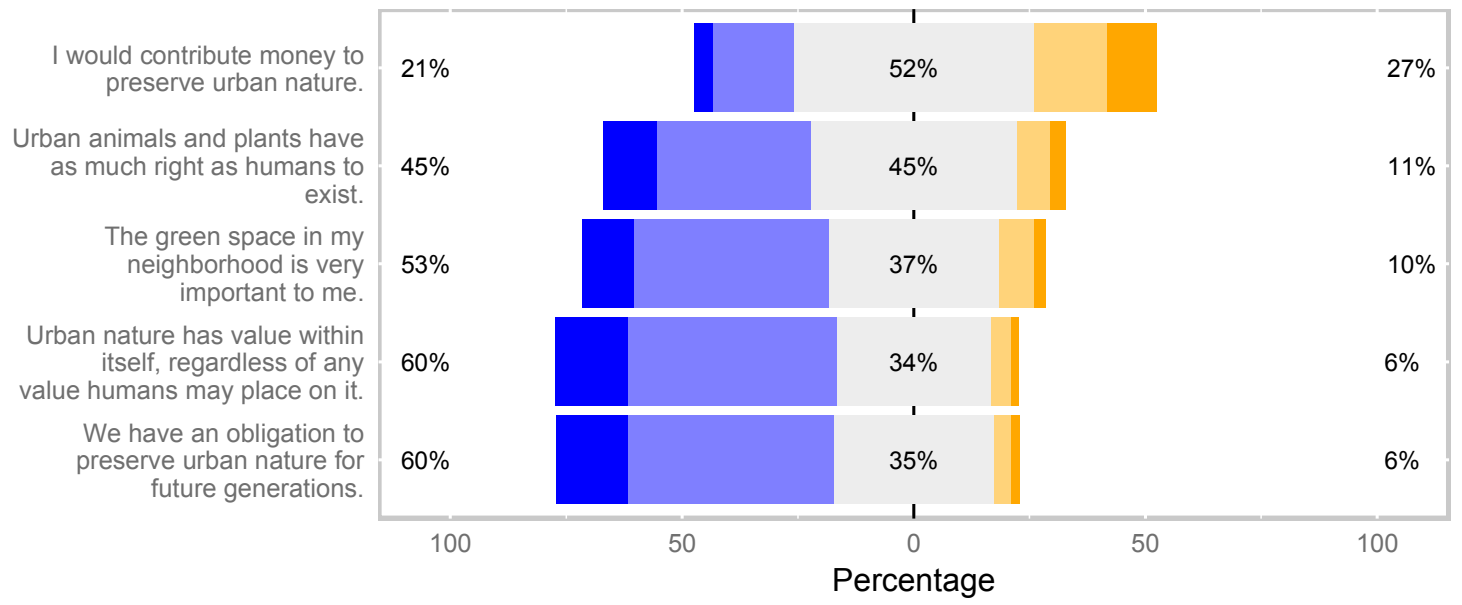

Response strongly agree agree neutral disagree strongly disagree

Figure 3. Respondents' attitude toward urban nature.

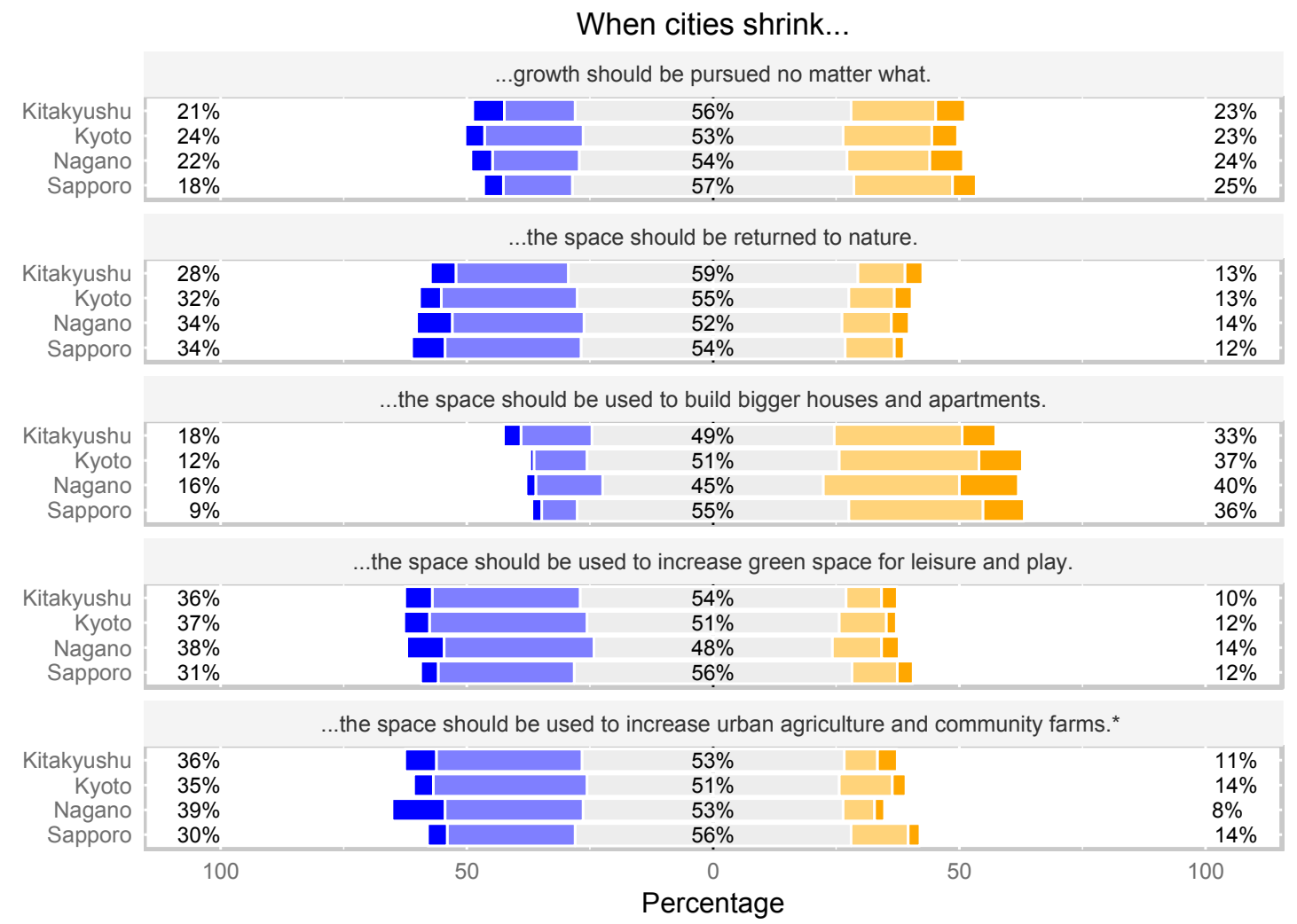

Response $\square$ strongly agree $\_$agree neutral disagree $\quad$ strongly disagree

Figure 4. Respondents' opinion on how to proceed when cities are shrinking.

\subsection{Respondents' Perception, Use, and Evaluation of IGS}

Most respondents (70\%) knew IGS in their neighborhood (Table 3). Among those, vacant lots, street verges, waterside and gap spaces were reported most often. Almost half of the respondents who knew IGS in their neighborhood perceived it as relatively biodiverse. Familiarity with IGS in the 
neighborhood did not differ significantly between cities, but perceived biodiversity did $\left(X^{2}(12)=29.37\right.$, $p<0.01)$ ). Nagano had the highest perceived biodiversity, Sapporo the lowest. Sex had no effect on familiarity or perceived biodiversity.

Most respondents who knew of IGS in their neighborhood did not use it for recreational purposes (79\%, Table 4), but some reported using it weekly or daily. Use frequency did not differ between the four cities. Respondents used IGS for wide variety of activities, including going for a stroll, exercise-oriented walking, playing with children, walking the dog, BBQs, general exercise, taking a rest, collecting insects, taking photos, observing plants and animals, fishing, doing nothing, and using it as a shortcut on the way to somewhere else. The most common reasons IGS users gave for preferring it over parks or gardens were that IGS was close to their home, was not crowded, had no use restrictions, and was wild and exciting with many and/or different species of plants and animals around. Most IGS users reported no problems with using IGS for recreational purposes, while littering was the most commonly mentioned problem encountered. Respondents (including non-users) had a wide variety of ideas to make using IGS easier. Main ideas included a minimum level of maintenance and management (such as picking up trash, removing dog droppings, planting flowers, mowing), adding facilities such as seating, improving accessibility by removing barriers such as fences, adding signs to show the space may be used, improve safety and/or safe appearance, and converting it to formal green space (e.g., park, community garden). However, some also emphasized there was no need to do anything, voicing concerns that increased use could cause IGS to lose its special characteristics (see also Section 3.3).

Table 3. Respondents' perception of IGS.

\begin{tabular}{ccc}
\hline Question Asked & Response Options $\mathbf{~}^{\text {1 }}$ & Answers (\%) \\
\hline How many informal green spaces & None & 30.4 \\
(as introduced above) exist in your & A few (1-5) & 44.5 \\
neighborhood? $(n=1000)$ & Some (5-10) & 14.8 \\
& Many (over 10) & 10.3 \\
\hline What types of informal green & Vacant lots & 73.6 \\
spaces do you know of in your & Structures (overgrown walls, fences, roofs etc.) & 34.8 \\
neighborhood? Please only select & Railway verges & 29.2 \\
spaces with vegetation other than & Street verges & 68.0 \\
parks, gardens or plazas. (multiple & Brownfields & 10.8 \\
answers possible; $n=696)$ & Waterside (river banks, river beds etc.) & 54.7 \\
& Power-line corridors & 15.8 \\
& Gaps (between walls or fences etc.) & 44.8 \\
\hline How many species of animals and & Very few & 4.5 \\
plants do you think live in & Few & 31.0 \\
informal green spaces? $(n=696)$ & Many & 38.8 \\
& Very many & 9.9 \\
\hline
\end{tabular}

\footnotetext{
${ }^{1}$ Response options are listed in order of appearance in the survey instrument.
}

Table 4. Respondents' use of IGS for recreational purposes.

\begin{tabular}{ccc}
\hline Question Asked & Response Options $\mathbf{1}^{\mathbf{1}}$ & Answers (\%) \\
\hline How often do you use & Never & 78.7 \\
informal green space for & Daily & 0.9 \\
recreation, exercise or play & Once a week & 6.2 \\
etc.? $(n=696)$ & Once a month & 5.0 \\
& A few times per year & 9.2 \\
\hline
\end{tabular}


Table 4. Cont.

\begin{tabular}{|c|c|c|}
\hline Question Asked & Response Options ${ }^{1}$ & Answers (\%) \\
\hline \multirow{10}{*}{$\begin{array}{l}\text { Why do you use informal } \\
\text { green space and not a park or } \\
\text { garden? }(n=148)\end{array}$} & It's near my home & 66.2 \\
\hline & It's wild and exciting & 19.6 \\
\hline & It's not crowded & 39.2 \\
\hline & There are more or different animals or plants & 19.6 \\
\hline & It has better privacy (nobody watching) & 9.5 \\
\hline & $\begin{array}{l}\text { There are no use restrictions } \\
\text { (e.g., no dogs, no ball play) }\end{array}$ & 23.6 \\
\hline & It can be used for many things (e.g., gardening) & 11.5 \\
\hline & There are no nice parks near my home & 12.2 \\
\hline & I don't have a garden or similar green space & 14.9 \\
\hline & Other & 6.8 \\
\hline \multirow{14}{*}{$\begin{array}{c}\text { Did you experience any } \\
\text { problems when using informal } \\
\text { green space? }(n=148)\end{array}$} & No & 62.8 \\
\hline & Hard to access (fence, signs etc.) & 8.8 \\
\hline & I was scared to use it & 8.8 \\
\hline & Dangerous animals & 5.4 \\
\hline & Dangerous plants & 4.1 \\
\hline & Danger of injury & 10.1 \\
\hline & Lots of litter & 19.6 \\
\hline & Conflict with the owner & 3.4 \\
\hline & Conflict with police & 0.0 \\
\hline & Conflict with other users & 2.7 \\
\hline & Criminals were present & 0.7 \\
\hline & Drug users were present & 0.0 \\
\hline & Prostitutes were present & 0.0 \\
\hline & Other & 2.0 \\
\hline
\end{tabular}

${ }^{1}$ Response options are listed in order of appearance in the survey instrument.

Benefits respondents most commonly associated with IGS were related to city greening, ecosystem services such as air filtration and cooling, wildlife habitat, and providing an opportunity for nature contact (Figure 5). While more respondents saw IGS as a space children can use to play, this was not true for leisure activities in general. Food-related benefits received the lowest agreement. Residents' opinion on IGS benefits differed between the four cities only regarding the ability of IGS to sequester carbon (Figure 5, Q15; H(3) = 10.06, $p<0.05 ;$ SP-NA, $p=0.002$ ), with agreement strongest in Nagano $(54 \%)$ and weakest in Sapporo (39\%). Women felt more strongly than men ( $\mathrm{W}=134,895, p<0.05)$ that every bit of green in the city is good (Figure 5, Q17), while other IGS benefit perceptions were not affected by sex. With increasing age respondents agreed significantly less with a number of IGS benefits related to recreation, child play, a more interesting neighborhood and the general benefit of green in the city (Figure 5, Q4/8/3/17; $p<0.01$ to $p<0.001$ ), but effect sizes were limited $\left(r_{s}=0.07\right.$ to $\left.r_{s}=0.13\right)$.

In contrast, respondents perceived littering, weeds and pest animals, as well as a disorderly look to be the main potential problems associated with IGS (Figure 6). However, IGS was mostly not perceived as a waste of space. Likewise, the common Japanese social issue of conflicts around noise associated with children's play was not seen as a problem related to IGS by most respondents. Five problems were perceived differently between the study locations: pest animals (Figure 6, Q2; $\mathrm{H}(3)=28.46, p<0.001$; SP-NA, $p<0.001$; SP-KY, $p<0.001$; SP-KK, $p=0.006$ ), weeds (Figure 6, Q6; $\mathrm{H}(3)=24.06, p<0.001$; all study location pairs $p<0.03$ except KY-KK), fire hazard (Figure 6, Q5; $\mathrm{H}(3)=14.15, p<0.01$; SP-NA, $p=0.033$; SP-KY, $p<0.001$; SP-KK, $p=0.002$ ), littering (Figure 6, Q9; $\mathrm{H}(3)=14.07, p<0.01$; SP-NA, $p<0.001$; NA-KY, $p=0.014$ ), and disorderly appearance (Figure 6, Q10; $\mathrm{H}(3)=14.61, p<0.01$; SP-NA, $p<0.001$; SP-KY, $p=0.006$ ). Women felt more strongly about liability, vandalism, criminals, danger to children, unwanted individuals and fire hazard than men (Figure 6, Q8/12/4/11/1/5; $p<0.05$ to $p<0.001)$, similar to how with increasing age respondents felt more 
strongly about vandalism, graffiti, disorderly appearance, danger to children and fire hazard (Figure 6, $\mathrm{Q} 12 / 7 / 10 / 11 / 5 ; p<0.05$ to $p<0.001 ; r_{s}=0.07$ to $\left.r_{s}=0.14\right)$.

Overall, respondents felt that IGS affected their daily lives to different degrees. Of all respondents, $40.1 \%$ felt IGS did not affect their daily lives for the better or the worse. On the other hand, $15.5 \%$ answered IGS made their daily life better, and $10.6 \%$ disagreed, stating it made their daily life worse. Finally, $33.8 \%$ perceived IGS as both a positive and negative influence on their daily lives. Respondents' IGS evaluation did not differ significantly between the four cities. While a detailed analysis of qualitative answers about the reasons how respondents felt IGS affected their daily lives goes beyond the scope of this paper, overall themes brought up were as follows. Overall, the ambiguity of IGS in terms of management, responsibility, ownership, and usability was perceived as a source of problems. Many respondents noted that some IGS influenced their daily lives positively, others negatively, leading to their overall evaluation of "both" in the previous question. Others commented such evaluation would likely depend not only on the IGS in question, but also on individual aesthetic and recreational preferences as well as individual attitudes in general and towards nature in particular, and on how IGS would be used.

What kind of benefits do you think informal greenspace can have?

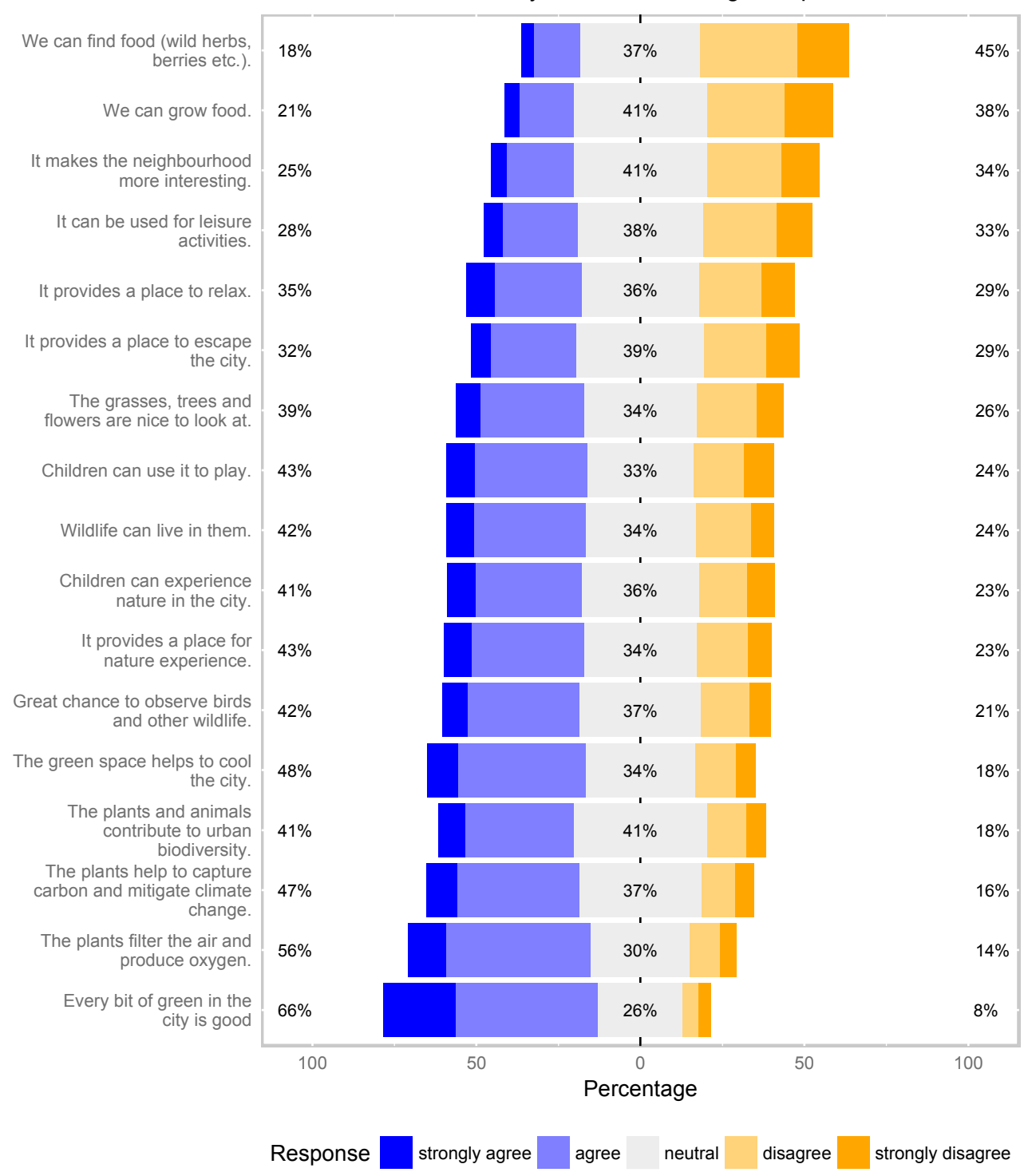

Figure 5. Respondents' level of agreement to potential IGS benefits. 


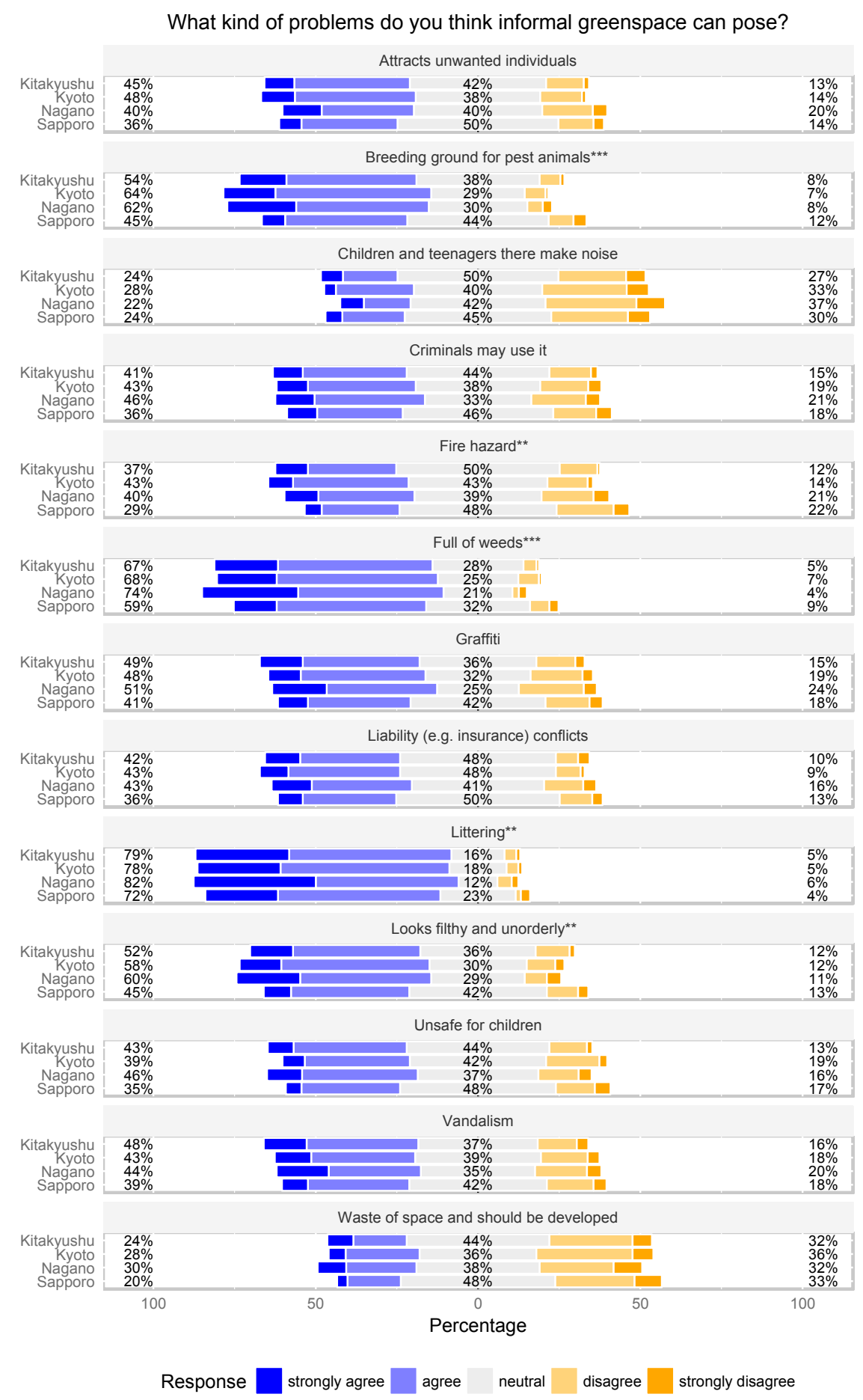

Figure 6. Respondents' level of agreement to potential IGS problems. Significant differences between the four cities are noted as ${ }^{*}(p<0.05){ }^{* *}(p<0.01)$, and ${ }^{* * *}(p<0.001)$.

\subsection{Respondents' Preferences for IGS Management: Goals, Approaches, Willingness to Participate}

Regarding management goals for IGS, respondents clearly favored preserving IGS as green space over redevelopment (Figure 7). On the other hand, not managing IGS was clearly disfavored. Opinions differed signficiantly between the four cities regarding the management goals of beautification (Figure 7 , Q2; H(3) $=11.78, p<0.01$; SP-NA, $p<0.001$; SP-KY, $p=0.009$; SP-KK, $p=0.036$ ), urban agriculture (Figure 7, Q10; H(3) = 17.59, $p<0.01$; SP-NA, $p<0.001$; SP-KK, $p=0.002$; NA-KY, $p=0.006$; KY-KK, 
$p=0.018$ ), and parking space (Figure 7, Q7; H(3) = 9.98, $p<0.05$; SP-KK, $p=0.004 ; \mathrm{KY}-\mathrm{KK}, p=0.011$ ). Women were more strongly opposed to not managing IGS (Figure 7, Q6; W=115669, $p<0.05$ ). With rising age, respondents were more strongly opposed to child recreation, animal conservation but also redevelopment as IGS management goals (Figure 7, Q5/1/9; $p<0.05$ to $p<0.001, r_{s}=0.07$ to 0.11 ). Respondents suggested a number of additional or alternative management goals, including using IGS for temporary events such as live music by indie bands or flea markets, off-leash areas for dogs, power generation (e.g., using solar panels), and building child-care or aged-care centers.

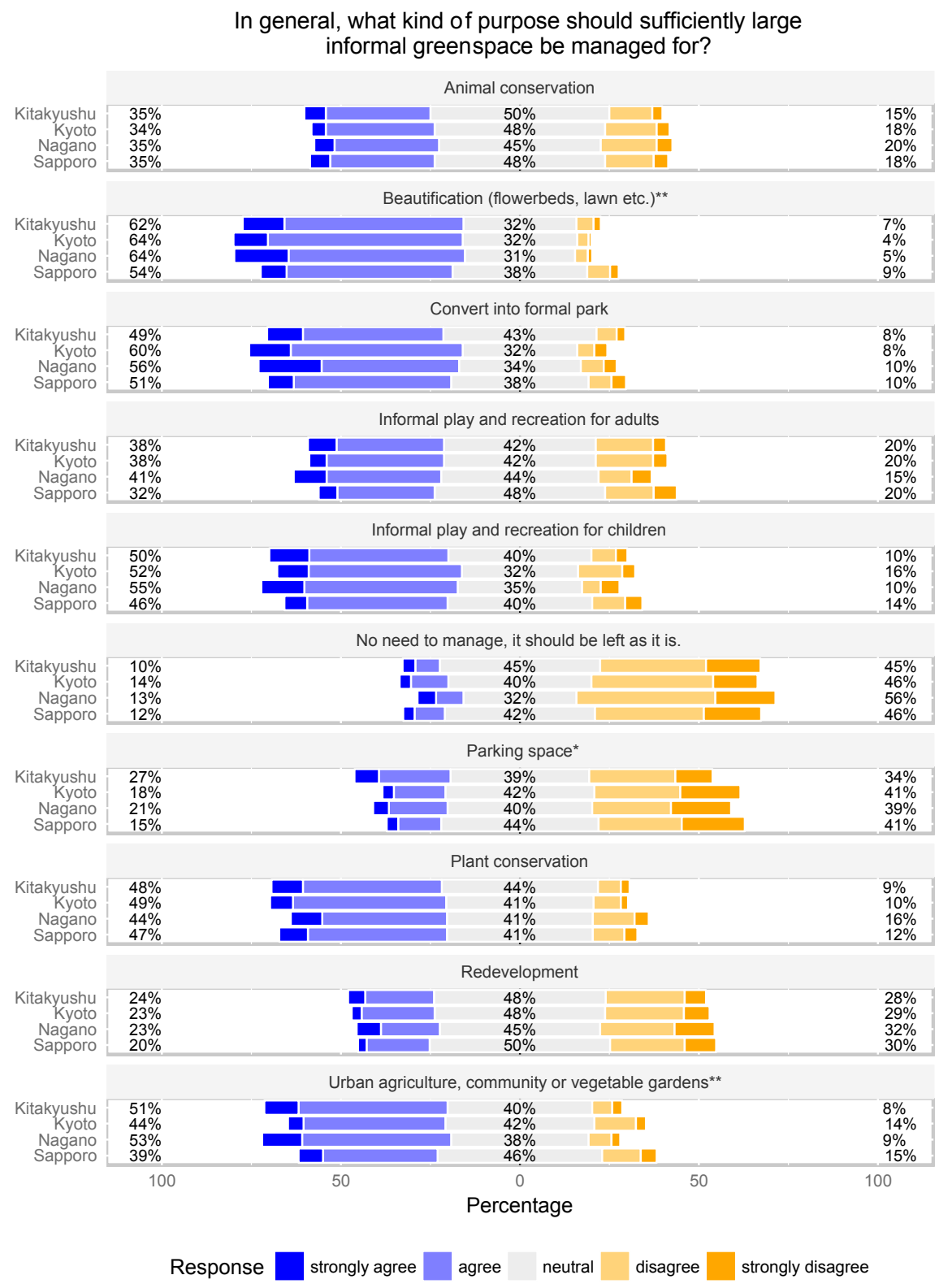

Figure 7. Respondents' preferred management goals for IGS. Significant differences between the four cities are noted as $*(p<0.05)$ and ${ }^{* *}(p<0.01)$.

In regard to management approaches (Figure 8), respondents thought IGS management was an issue of concern for residents in the neighborhood. Yet while residents were perceived to know better how to manage IGS than the city administration, respondents still thought the administration to be responsible for management. Qualitative responses clarified that this seemingly contradictory result was partly based on the perception that the city administration was shirking responsibilities, leaving 
residents to deal with problems without sufficient support. Overall, respondents were slightly in favor of stricter management and IGS use only with permission, while placing the liability with users. Respondents largely agreed participatory IGS management would improve its appearance, but felt both financial and other support by the city administration to be necessary. They also favored using IGS long-term over temporary use.

Significant differences in opinions on management approaches were found between the cities for some questions, and the extremes in opinion were as follows. Respondents rejected IGS use without permission in Kyoto (35\% vs. 17\%) more strongly than in Kitakyushu (24\% vs. 24\%; Figure 8, Q5; $\mathrm{H}(3)=10.01, p<0.05 ; \mathrm{NA}-\mathrm{KY}, p=0.041, \mathrm{KY}-\mathrm{KK}, p=0.003)$. Respondents were most optimistic that resident IGS management would improve its appearance in Nagano (38\% vs. 8\%), but least optimistic in Kyoto (27\% vs. 14\%; Figure 8, Q7; H(3) = 11.00, $p<0.05$; SP-NA, $p=0.008$, NA-KY, $p=0.003$; NA-KK, $p=0.049)$. Similarly, respondents were more convinced financial support for management would be necessary in Nagano (43\% vs. 9\%) than in Kyoto (36\% vs. 14\%; Figure 8, Q8; H(3) = 8.95, $p<0.05$; SP-NA, $p=0.035$; NA-KY, $p=0.015 ; \mathrm{KY}-\mathrm{KK}, p=0.042)$. Finally, long-term IGS use had the highest support over temporary use in Nagano (41\% vs. $8 \%$ ) and the lowest in Kyoto (32\% vs. $11 \%$; Figure 8 , $\mathrm{Q} 10 ; \mathrm{H}(3)=10.13, p<0.05$; NA-KY, $p=0.012 ; \mathrm{KY}-\mathrm{KK}, p=0.005)$. Women were less strongly in favor of placing the liability with users than men (Figure 8, Q6; $W=115,950, p<0.05$ ), but sex did not affect preference for other management approaches. With rising age, respondents favored IGS management following strict rules (Figure 8, Q4; $p<0.05, r_{S}=-0.07$ ) and requiring permission before using IGS (Figure 8, Q5; $p<0.01, r_{s}=-0.10$ ).

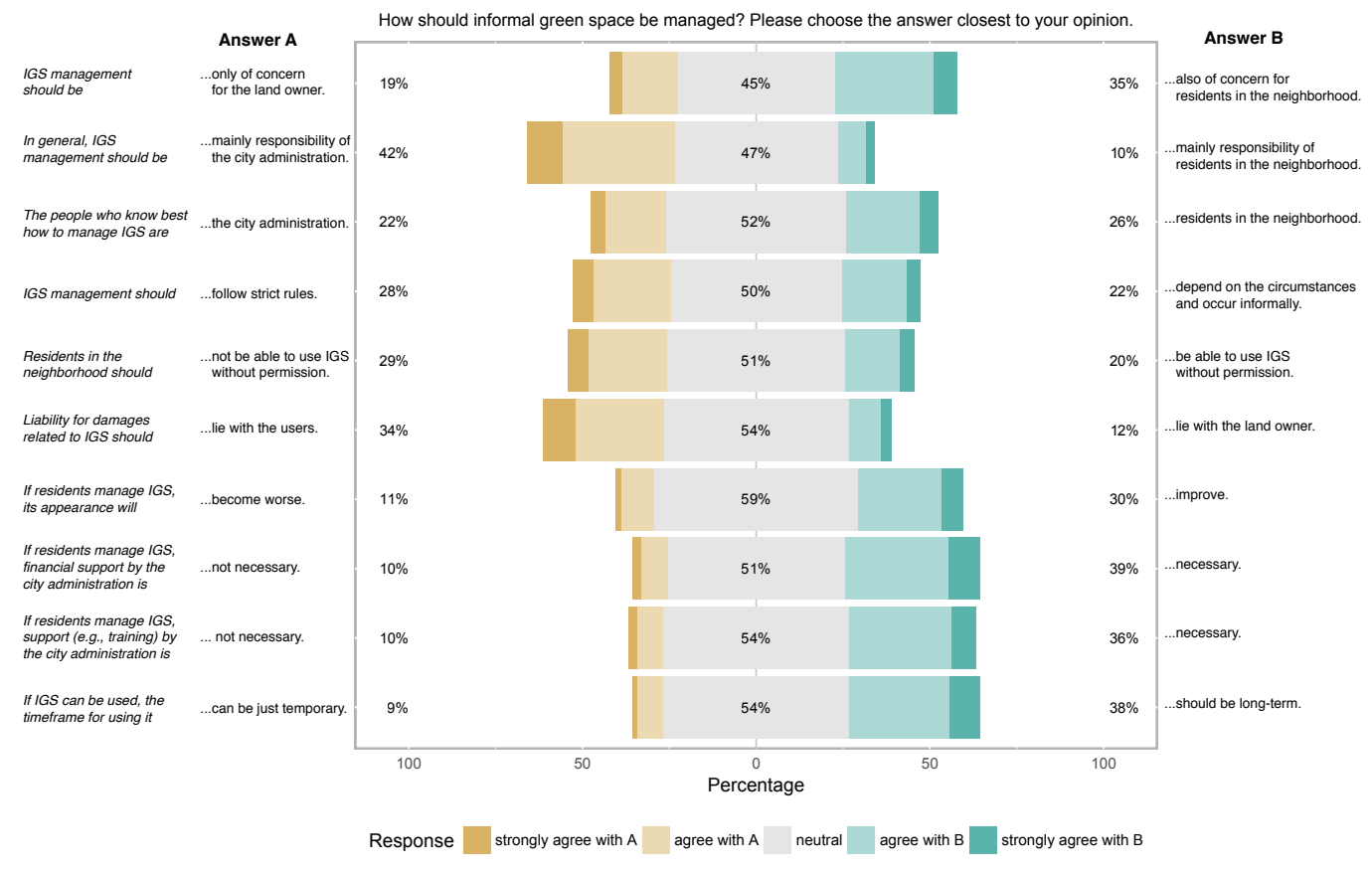

Figure 8. Respondents' opinion on approaches to IGS management.

Willingness to participate in participatory IGS management showed that less than $20 \%$ of respondents wanted to contribute, and less than $10 \%$ wanted to try organizing or leading such activities (Figure 9). On the other hand, when asked about concrete activities, respondents were more positive towards participation. However, a large number of respondents strongly disagreed across all types of participation. The only significant differences in responses between the four cities was in willingness to pick up trash (Figure 9, Q6; H(3) = 12.36, $p<0.01$; SP-NA, $p=0.004$; NA-KY, $p=0.004$ ) and willingness to plant flowers or trees (Figure 9, Q8; $\mathrm{H}(3)=12.25, p<0.01$; SP-NA, $p<0.001$; NA-KY, $p=0.016)$. Men were more willing to contribute time, skills, and money to IGS management, were 
more willing to participate monthly or weekly, try themselves at organizing or leading, and were more willing to mow, build equipment or collaborate in research (Figure 9, Q1-5/7/9-10; $p<0.05$ for money, $p<0.01$ for all others). With rising age, respondents were less willing to participate in planting activities (Figure 9, Q8; $p<0.05, r_{s}=0.08$ ) or in building play equipment (Figure 9, Q9; $p<0.001$, $\left.r_{s}=0.12\right)$. Respondents commented in qualitative responses that participative IGS management could be integrated into traditional local structures of community management (e.g., neighborhood associations), but also stressed that participation should not become a community duty (such as cleaning street gutters still is in many urban neighborhoods).

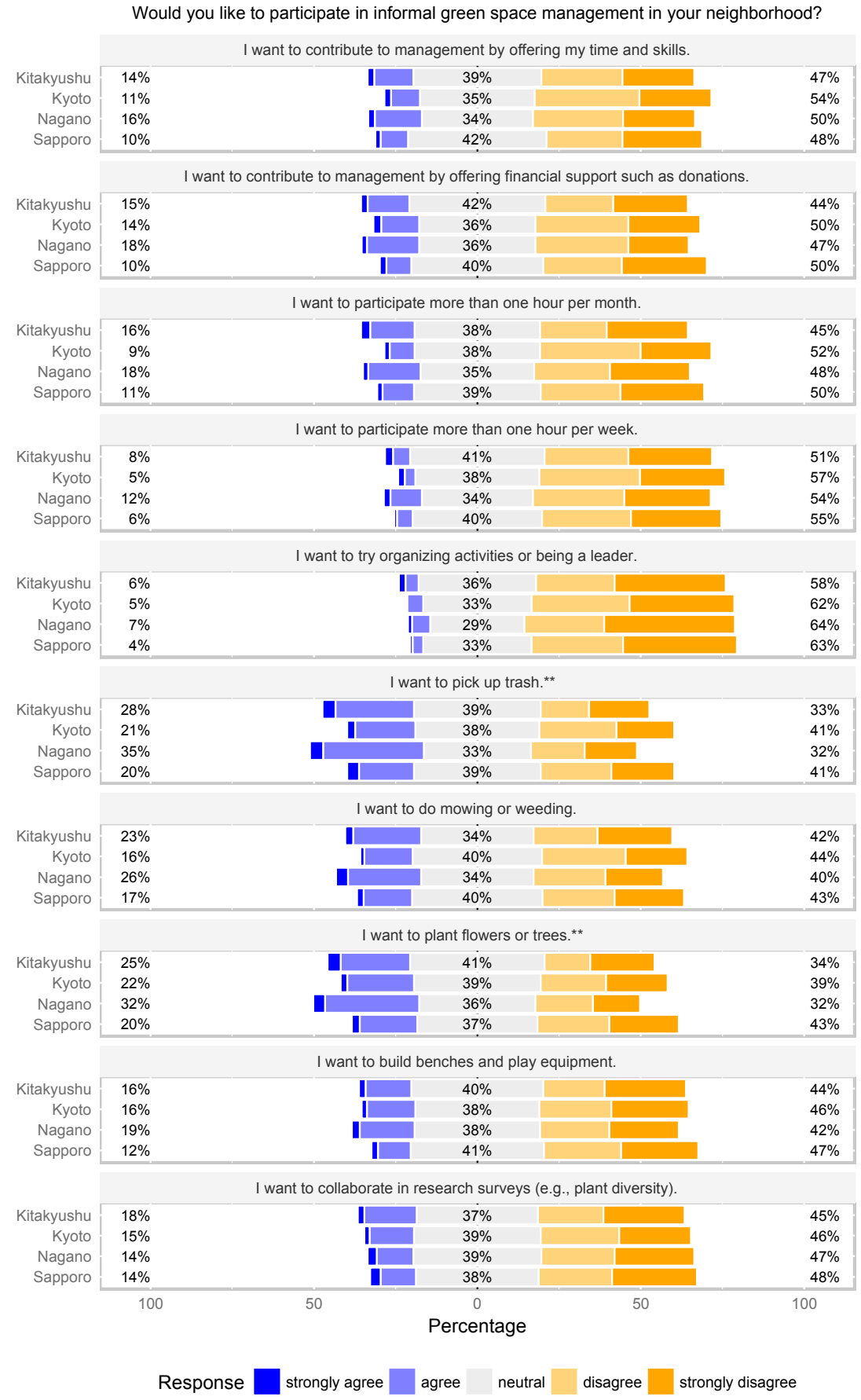

Figure 9. Respondents' willingness to participate IGS management. Significant differences between the four cities are noted as ${ }^{* *}(p<0.01)$. 


\subsection{Multiple Correspondence Analysis of Key IGS and Demographic Variables}

A multiple correspondence analysis of key IGS variables (number of IGS known in the neighborhood, perceived number of species living in IGS, perceived influence of IGS on everyday life, frequency of recreational IGS use) and demographic variables (level of educational attainment, household income, housing type, study location) was performed to explore relationships in the data through multivariate analysis. Likert-scale questions (perception of benefits and problems of IGS, attitude toward management goals and style) were excluded, as their addition did not substantially increase the variation explained and their inter-scale relationships were already analyzed using Cronbach's alpha. The results (Figure 10) show a clear distinction between respondents who knew and did not know IGS in their neighborhood. Furthermore, number of IGS known in the neighborhood seemed to be associated with perceived number of species in IGS, frequency of recreational use, and demographic characteristics such as detached housing with garden, higher educational attainment level, higher household income and the study location Nagano. However, the displayed first two dimensions only explain a cumulative variation of $14 \%$ (unadjusted).

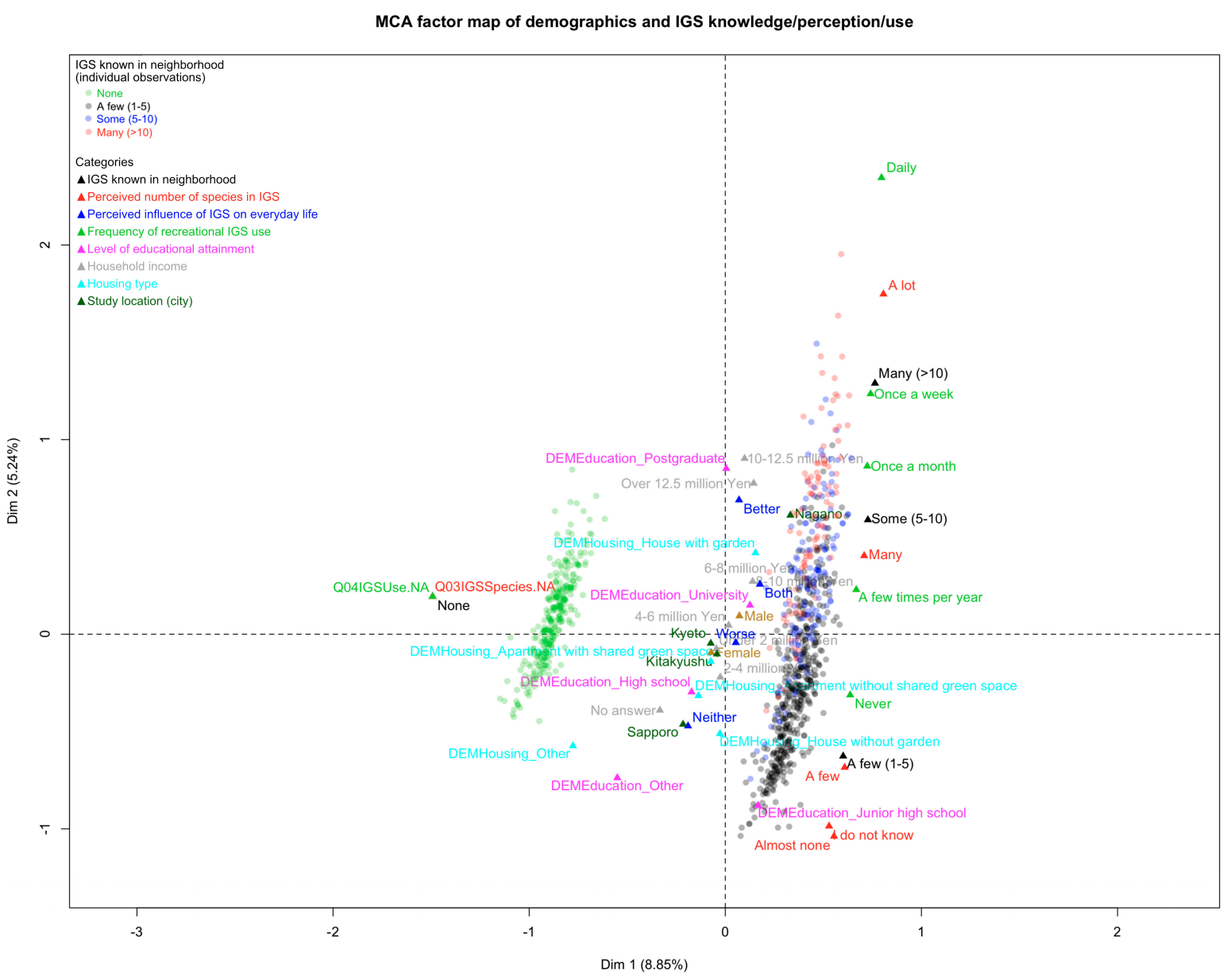

Figure 10. Multiple correspondence analysis of key IGS and demographic variables.

\section{Discussion}

\subsection{Perception, Evaluation, and Use of IGS}

The results of this survey suggest IGS is a part of everyday life and a common feature of the urban landscape, not only in Sapporo, where IGS in Japan was first studied, but also across shrinking Japanese cities. Furthermore, the findings provide strong evidence supporting the following conclusions from 
prior IGS research in Japan $[23,25]$. Many respondents perceive IGS to be biodiverse and to possess a range of potential benefits, from ecosystem services such as air filtration and cooling to wildlife habitat and opportunities for nature contact. Despite the near-absent discussion of recreational IGS use in the Japanese literature, every fifth respondent across all cities reported already engaging in such use-a majority of them without encountering problems. Proximity was again the most common reason why respondents used IGS, a topic that merits renewed attention as Japan's population ages and its mobility declines. On the other hand, as in prior research [23], many respondents felt IGS affected their daily lives in both positive and negative ways, with littering, weeds and pest animals, and the aesthetic appearance of IGS identified as major potential problems. These findings underline how important it is both to realize the potential of IGS and develop adequate approaches to manage it, especially in shrinking Japanese cities.

Differences between earlier results and this study were mostly in degree, not direction. Overall, fewer respondents knew IGS in their neighborhood or used it for recreational purposes in Sapporo in this study than in the postal survey conducted in 2012 [23]. These differences could be the result of a slight bias in responses of the original postal survey towards residents interested in the topic. In contrast, differences were less pronounced in regard to evaluation as well as perceived benefits and problems. Following the recommendations outlined in the earlier study, it is thus important to take a closer look at residents' preferences for management goals and approaches.

\subsection{Preferred Management Goals}

Respondents preferred active IGS management to a hands-off approach. Furthermore, they strongly favored management as green space over conversion to parking space or other urban land use. One such management goal is the creation of new parks using IGS where size and characteristics are suitable. These results are in line with earlier research that found Japanese respondents are overall hesitant to embrace the concept of urban wilderness, a concept that has figured prominently in work on IGS from Europe, North America and Australia [27,28,39-50]. Yet this does not imply that residents do not perceive the value of IGS as a different kind of urban green space. However, it suggests cultural factors could be influencing residents' perception and evaluation of IGS, something that has been suggested before in more general discussions of nature perception and culture [26,51]. This, again, may be a matter of degree rather than direction, as some respondents critical of IGS in Australia also mentioned impressions of neglect and abandonment as reasons for their negative perception of IGS. What follows is a dilemma: on one hand, vacancy often has negative cultural associations [52], while on the other hand a freedom of purpose can be a freedom from purpose, opening up space and possibilities that would otherwise not exist. Such notions have been explored in detail in prior work on IGS [53-55]. This issue then brings into focus more general opinions on using space in shrinking cities.

In their opinions about strategic directions for shrinking cities in general, respondents not only favored using space that becomes available for recreational green space and urban agriculture, they also supported giving up land use for human purposes to return it to nature. In contrast, respondents rejected using space opened up through population decline to increase housing size, even though Japanese houses and apartments are on average much smaller than housing in Western cities. These opinions align well with calls by researchers to focus on contact with nature and green infrastructure as a source of improved human wellbeing $[4,56]$. In a larger context, the results may reflect a shift in focus from material wealth to non-material wellbeing in the Japanese public that has occurred since the early 1970s (Figure 11, [57]). Overall, respondents' opinions signal support for Japanese urban green planning to expand its ambitions beyond the unambitious current policies, which often target only preserving existing green space rather than creating new ones. As budget constraints are partly to blame, the question then is to what degree participatory management approaches are supported by residents. 


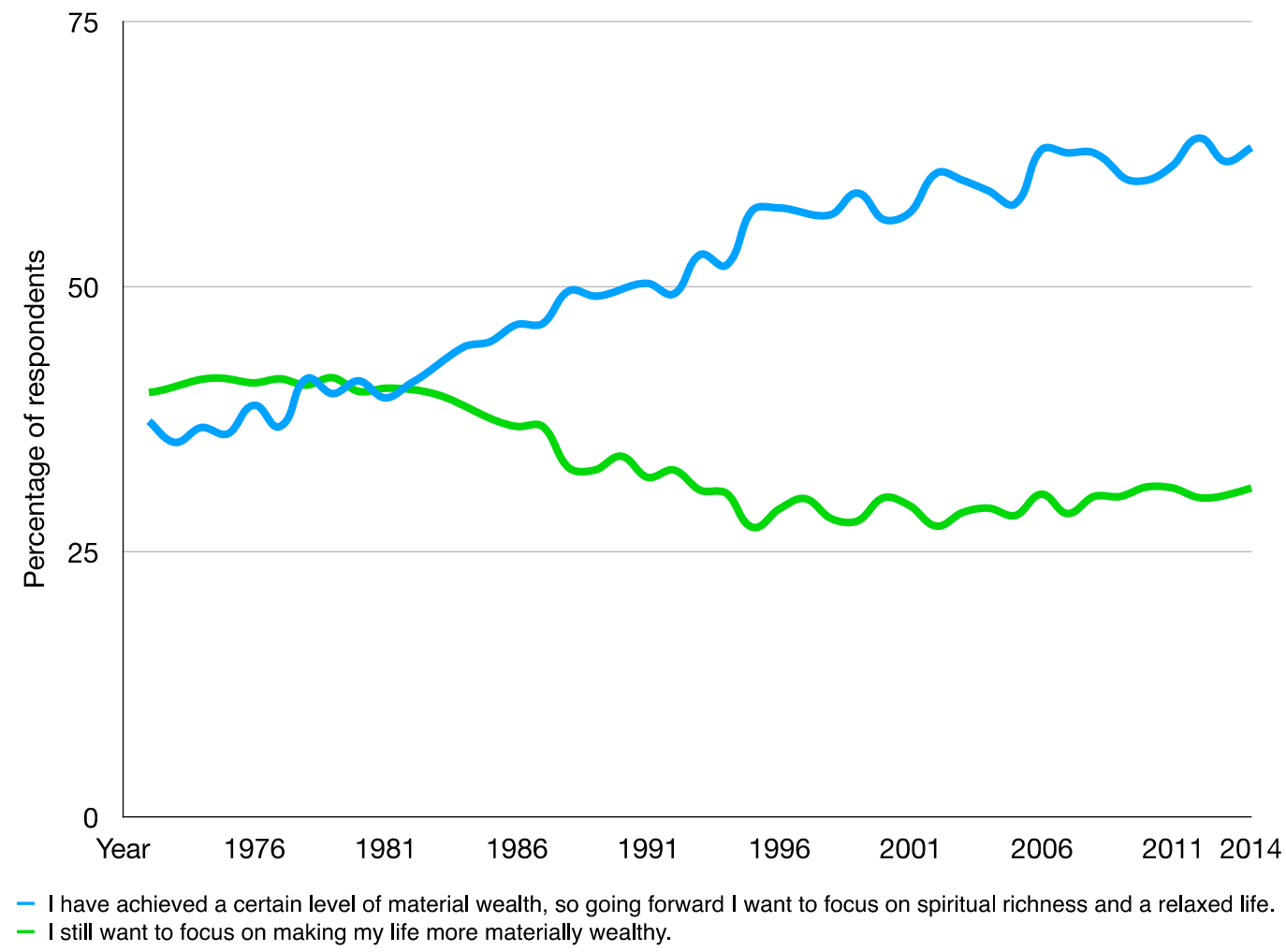

Figure 11. Long-term shift in life goals from material to non-material wellbeing in the Japanese public [57].

\subsection{Preferred Management Approaches}

Despite numerous benefits participatory IGS management could provide (e.g., realizing recreational potential, reducing financial burden to public funding etc.), the results of this survey suggest that residents will only accept such arrangements if they think it will improve IGS appearance-a primary concern reflected throughout perceived IGS benefits and problems as well as preferred IGS management goals. However, respondents did expect IGS appearance would improve through participatory management. Having residents manage IGS then stops being simply a strategy proposed by scholars to solve surrounding issues, and emerges as a new management approach supported by both professionals and stakeholders. This expected positive outcome also provides the basis on which the details of participatory IGS management can be discussed.

Principal issues of participatory IGS management are the questions of whom it should concern, and who should be responsible for it. It is not surprising that most respondents identified IGS management as a topic of concern for those living in the neighborhood, not just the land owner, as many knew of IGS in their neighborhood and felt it affected their daily lives. Yet at the same time, most saw the main responsibility for managing IGS lying with the city administration-even though overall respondents thought residents in the neighborhood would know better than the administration how such management should happen. This shows IGS management is situated in a triangle of concerned parties-owners (whether present/known or absent), neighbors and the city administration.

The opinion that taking care of land is an issue of concern to neighbors is not unique to IGS. Regulations across different countries affect everything from how houses may be built to how private green space should look. However, with IGS a number of complicating factors are introduced. First, depending on the type of IGS, the degree to which appearance and management is considered an issue likely varies, both among land owners and neighbors-a gap between walls or fences likely draws less attention than an overgrown vacant lot or fence. The issue becomes even more problematic if the owner is absent (e.g., living in a different area, corporate or public owner) or unknown, a problem 
that has lead the Japanese Ministry of Land, Infrastructure and Transport to produce over 300 pages of guidelines for dealing with unclear land ownership [58]. Not only does this mean the owner may be less invested in managing the space, neighbors may also have a harder time communicating their concerns about the space. This trend is to some degree exacerbated by land ownership fragmentation, which can lead to the generation of informal green spaces even in growing cities such as Tokyo [59]. Furthermore, eminent domain (or resumption/expropriation) is an exceedingly complicated issue in Japan $[60,61]$. On the other hand, social pressure can be perceived by owners as meddling in someone else's affairs. In the context of rapid aging, property maintenance can also be a task older people may no longer be physically able to carry out, creating a potential source of neighborhood friction. Even if relevant regulations exist, it may be difficult for the city administration to enforce them, and providing assistance in managing privately owned IGS would require using already strained public funding. A participatory IGS management framework would thus need to mediate between neighbors and space owners without the city administration abdicating from the responsibility respondents perceive it to have.

Three core issues are likely to play an important role in the outcome of participatory IGS management. First, the variety of IGS characteristics (type, size, ownership etc.), the inherent subjectivity of IGS evaluation, and the social nature of the relationships involved would favor a flexible approach to management. However, survey results show a plurality of respondents favored strict rules over case-by-case and informal management. This further supports a role of the city administration in providing a framework for IGS management, even though such a framework would need enough inherent flexibility to process diverse cases. Second, a principal goal of IGS management should be to realize its potential for recreation [29] and conservation [62,63] —a goal this survey shows is supported by respondents. However, a plurality of respondents rejected allowing residents to use IGS without permission. This means participatory IGS management would require a mechanism to establish consent to IGS use, whether through communal opt-in or opt-out approaches or incentive/disincentive-based arrangements. For temporary uses, agents involved in the event planning can facilitate this process [64], while in other cases non-governmental organizations fill this role (e.g., 596 Acres in New York). Third, because the issue of liability has been identified as an important barrier to IGS use, participatory IGS management should attempt to at least ameliorate this problem. Liability has a long history alongside a record of court decisions seeking to solve this problem [65]. However, current arrangements often require land owners to make IGS inaccessible to avoid liability, thus reducing its use value for recreation (for conservation, the outcome likely depends on the particular species and types of barriers to movement involved). In this case, respondents in general saw IGS users liable for damages, suggesting that this issue could be ameliorated, possibly by offering reduced owner liability in exchange for consenting to IGS use by residents. Once the three core issues above have been addressed, what remains to be discussed are necessary support and timeframes of IGS use.

The history of participatory green space management shows that simply handing over such tasks to residents can easily fail without necessary support. While participatory approaches are often intended to reduce financial pressure on strained public finances, respondents were clear in their assessment that financial support by the city administration would be necessary if residents were to manage IGS. This has been pointed out by Arnstein in her "ladder of citizen participation" as early as 1969 [66], but actual implementation has been slow. On the other hand, financial support is likely not sufficient. Respondents acknowledged this, and while the need for non-financial support through training opportunities, knowledge sharing or provision of facilities may seem obvious, it merits confirmation to ensure such support is made part of participatory management arrangements.

\subsection{Willingness to Volunteer}

Participatory IGS management in principle draws on resources provided by residents to achieve its goals, meaning its viability depends on how willing residents are to engage in such activities. Only 
a minority of respondents was willing to participate in IGS management either through contributing time or money. Yet over $10 \%$ of respondents were willing to participate one hour or more per month. In comparison, Takase and colleagues [67-70], who have done extensive work on participatory green space in Japan, found in a survey of residents interested in participatory green space activities that their average willingness to work was 11.6 days per year [31]. On this basis, they recommended a frequency of one activity per month. This could prove sufficient, as managing IGS likely requires less effort than ordinary green space maintenance. Prior research even warns of the danger of applying traditional planning tools or standards to IGS, which can lead to diminished recreational potential as attractive features of IGS are lost [71]. Even in a Japanese context, where wild urban nature seems to be less valued in comparison to Europe, respondents emphasized in this study that even a minimal level of IGS management could improve both perception and recreational value of IGS. Some participants also voiced concerns that over-management might risk losing the characteristics making IGS special.

In regard to possible ways of organizing participation, respondents proposed drawing upon traditional institutions of local self-management such as neighborhood associations (chōnaikai). These associations seem to be an obvious choice, but on further examination a number of problems emerge. First, the very process of depopulation that drives an increase in vacant lots and other IGS is, together with other changes to Japan's social fabric, leading to a decline in organization level among neighborhood associations. Furthermore, neighborhood association membership is often limited by social class or housing type, where apartment dwellers and/or renters are not invited to participate as they are seen as transitory residents with no stake in the neighborhood. Second, neighborhood associations also have a history of resisting changes to the status quo, which leads back to their conservative background as a state co-opted tool of maintaining the public order during the second world war [72]. During the 1970s environmental pollution protests, neighborhood associations often acted to suppress protest and thus constituted an important barrier to institutionalization. As a result, it might be prudent to avoid framing participatory IGS management as a civic duty, but rather organize it based on interest and by emphasizing benefits to participating. Indeed, Takase and colleagues show that participation in green space conservation efforts is associated with benefits similar to those attributed to IGS [31]. Research on community gardens has also found that participatory management can help to strengthen community ties [73-75], a process that might alleviate some of the issues resulting from social change and depopulation. Existing examples from Japan could serve as references for implementing participatory arrangements, such as the conversion of power-line corridor IGS into a community garden in Nagoya or the informal urban agriculture practiced along a riverbank in Sapporo [76]. Such examples also propose a potential solution to the problem of environmental gentrification associated with increasing traditional types of urban green spaces [56,77].

\subsection{Main Contributions of This Study to Our Understanding of IGS}

This study contributes to our understanding of IGS in three major ways. First, unlike existing exploratory work $[23,25]$, this study is based on a representative sample, so the results can (with some limitations, see below) be generalized for the four cities. The results thus make a compelling argument for the importance of IGS in general and IGS planning specifically. Second, this study is the first comprehensive examination of residents' preferences for IGS management goals and approaches using a large sample rather than exploratory or qualitative (e.g., case studies, interviews etc.) methods. The study thus provides insight into residents' attitudes that goes beyond common methods in participatory planning (such as public consultations, which usually employ an opt-in approach). Third, the study probes the feasibility of participatory IGS management by examining residents' willingness to participate, applying prior groundbreaking work on participatory green space management in Japan to informal green spaces for the first time. These major contributions provide a solid basis on which more general principles for IGS planning can be proposed. This task is taken up in the conclusion. 


\subsection{Limitations}

This study has a number of limitations. While the sample is representative for the four study locations, all of these cities are projected to be shrinking, so results could differ for urban areas still experiencing growth (e.g., Nagoya, Tokyo). As the survey was conducted online, the opinion of residents without Internet access may not be adequately represented. However, research has shown online surveys to be in general robust and reliable. Another limitation is the age range of respondents (20-69 years). Past research, as well as response in this survey, has shown that IGS plays an important role for children's recreation, but due to constraints by the survey provider, this study was not able to collect data underage respondents. What role IGS plays for recreation of adults over 70 is unclear, but this age group was also not included in this study. The sample also showed a large number of respondents to have a neutral opinion about many questions. While this may indicate a lack of interest in the topic, including these responses avoids the potential non-response bias found in postal surveys. Due to budget constraints, this survey was limited to shrinking cities in Japan, even though participatory management is likely also of interest to shrinking municipalities in other countries. The scarcity of prior research on both IGS in Japan and participatory IGS management in general also limits comparisons and possible discussion of similarities and differences, an issue that should be addressed by additional future research.

\section{Conclusions}

This study has analyzed perception, use and management preferences of residents in four major shrinking Japanese cities on the basis of a large-scale $(n=1000)$ representative online survey. The results have important implications for planning and management of IGS in shrinking Japanese cities, and provide clear directions for managing non-traditional green spaces to urban planners. Drawing upon the reported findings, the following eight major planning principles derived from the findings are proposed as a potential basis of future strategic IGS planning policy in Japan:

1. IGS is an integral part of the everyday urban landscape and residents' daily lives. As such, planners should consider ways to integrate it into existing green plans.

2. IGS has a wide variety of potential benefits and problems, but whether IGS affects residents' positively or negatively depends on how it is managed. Current (non-)management produces positive outcomes for some residents, but remains suboptimal.

3. Residents strongly support recreation, urban agriculture and conservation as three central functions and goals for IGS management. These preferences should form the basis of IGS management planning.

4. Residents strongly support recreation, urban agriculture and returning space to nature as overarching uses for space opened up through urban shrinkage. These preferences question current efforts of national, regional and local governments to attract new residents and halt or even reverse urban shrinkage. Instead, residents' preferences should form the basis for larger strategic urban planning.

5. The city administration is expected to play a role in managing IGS, even in participatory planning arrangements. Participatory management should not lead to a complete retreat of government involvement in managing IGS, but actively draw on the local knowledge of residents.

6. Realizing the potential of IGS for recreation likely requires a clear framework of rules around IGS use, mechanisms of consent to improve accessibility, and strategies to ameliorate liability issues. These three requirements indicate an important role to play for planners and green space managers.

7. Participatory IGS management is expected to improve the urban landscape aesthetic. To achieve this outcome, residents require both financial and non-financial support from the city administration. 
8. A small but significant minority ( $10 \%)$ of residents is willing to participate through offering time, skills and donations. As IGS only requires limited management to be evaluated considerably higher by residents, the basis of participatory IGS management likely exists. Participation should be voluntary, not forced.

The important role IGS plays for residents and as a common type of space in the urban landscape suggests further research is necessary to address questions that could not be covered in this study. First, it remains unclear whether IGS perception, use, and management preferences of residents in shrinking cities are identical or similar to those of residents in Japanese cities with growing population (e.g., Nagoya, Tokyo). Future research should explore what role this and other factors play, both in Japan and internationally. Second, we still know little about perception, use, and management preference of underage residents and residents over 70 years of age. Such research would likely need to draw on non-internet-based research methods. Third, despite recent work on the topic, examples of participatory IGS management are understudied, making it difficult for planners to learn from real-world cases. A detailed case comparison study could provide valuable insights on benefits and drawbacks of different levels of informality or regulation in IGS management, ideally identifying best-practice examples. Fourth, the recent attention on green infrastructure has raised the question of how IGS can function as one type of green infrastructure, including in comparison to private green spaces and associated participatory management approaches. Finally, the thorough understanding of residents' attitude toward participatory IGS management on which the proposed planning principles are based is currently limited to Japan. Further research is necessary to understand to what degree the principles hold true in other geographic and cultural contexts.

Supplementary Materials: The following are available online at www.mdpi.com/2073-445X/6/3/59/s1, File S1: Survey instrument (In Japanese), File S2: Raw survey dataset (In Japanese).

Acknowledgments: I would like to thank all respondents for participating in this study, and the members of the FEAST Project for their assistance with this study. This research was supported by the FEAST Project (No. 14200116), Research Institute for Humanity and Nature (RIHN), an Early Career Researcher Support Grant by RIHN, and by JSPS KAKENHI Grant Numbers JP17K08179, JP17K15407.

Conflicts of Interest: The author declares no conflict of interest. The funding sponsors had no role in the design of the study; in the collection, analyses, or interpretation of data; in the writing of the manuscript, and in the decision to publish the results.

\section{References}

1. Keniger, L.; Gaston, K.; Irvine, K.; Fuller, R. What are the Benefits of Interacting with Nature? Int. J. Environ. Res. Public Health 2013, 10, 913-935. [CrossRef] [PubMed]

2. Lee, A.C.K.; Maheswaran, R. The health benefits of urban green spaces: A review of the evidence. J. Public Health 2011, 33, 212-222. [CrossRef] [PubMed]

3. Bratman, G.N.; Daily, G.C.; Levy, B.J.; Gross, J.J. The benefits of nature experience: Improved affect and cognition. Landsc. Urban Plan. 2015, 138, 41-50. [CrossRef]

4. Tzoulas, K.; Korpela, K.; Venn, S.; Yli-Pelkonen, V.; Kaźmierczak, A.; Niemela, J.; James, P. Promoting ecosystem and human health in urban areas using Green Infrastructure: A literature review. Landsc. Urban Plan. 2007, 81, 167-178. [CrossRef]

5. Van den Berg, M.; Wendel-Vos, W.; van Poppel, M.; Kemper, H.; van Mechelen, W.; Maas, J. Health Benefits of Green Spaces in the Living Environment: A Systematic Review of Epidemiological Studies. Urban For. Urban Green. 2015, 14, 806-816. [CrossRef]

6. Naumann, S.; Davis, M.; Kaphengst, T.; Pieterse, M.; Rayment, M. Design, Implementation and Cost Elements of Green Infrastructure Projects; Ecologic Institute and GHK Consulting: Berlin, Germany, 2010.

7. Yokohari, M.; Bolthouse, J. Planning for the slow lane: The need to restore working greenspaces in maturing contexts. Landsc. Urban Plan. 2011, 100, 421-424. [CrossRef]

8. Kobayashi, R.; Sakai, A. Study on transition of regenerating for city park in Sapporo city. J. City Plan. Inst. Jpn. 2008, 43.3, 583-588. [CrossRef] 
9. 2014 Status of Urban Green Space per Capita on Prefectural Basis. Available online: http: / / www.webcitation.org/query?url=https\%3A\%2F\%2Fwww.mlit.go.jp\%2Fcrd\%2Fpark\%2Fjoho\% 2Fdatabase\%2Ft_kouen\%2Fpdf\%2F04_h26.pdf\&date=2017-08-24 (accessed on 24 August 2017).

10. Eanes, F.; Ventura, S.J. Inventorying Land Availability and Suitability for Community Gardens in Madison, Wisconsin. Cities Environ. CATE 2015, 8, 2.

11. Savino, S.D.M. Facilitating Social-Ecological Transformation of a Vacant Lot on an Urban Campus: The Houston-Congolese Connection. Cities Environ. CATE 2015, 8, 4.

12. Delgado, C. Answer to the Portuguese Crisis: Turning Vacant Land into Urban Agriculture. Cities Environ. CATE 2015, 8, 5.

13. Dennis, M.; James, P. User participation in urban green commons: Exploring the links between access, voluntarism, biodiversity and well being. Urban For. Urban Green. 2016, 15, 22-31. [CrossRef]

14. Gasperi, D.; Pennisi, G.; Rizzati, N.; Magrefi, F.; Bazzocchi, G.; Mezzacapo, U.; Centrone Stefani, M.; Sanyé-Mengual, E.; Orsini, F.; Gianquinto, G. Towards Regenerated and Productive Vacant Areas through Urban Horticulture: Lessons from Bologna, Italy. Sustainability 2016, 8, 1347. [CrossRef]

15. Sugita, S.; Doi, Y. A Fundamental Study on Stewardship of Public Space by Local Community Groups. J. City Plan. Inst. Jpn. 2012, 47, 469-474. [CrossRef]

16. IPSS Regional Population Projections for Japan: 2010-2040 (March 2013). Available online: http:/ / www.ipss. go.jp/pp-shicyoson/e/shicyoson13/t-page.asp (accessed on 19 April 2016).

17. Japanese Ministry of Land, Infrastructure and Transport. Toshi Kōenhō Unyō Shishin (dai 2 ban) (In Japanese; Urban Park Law Operation Guidelines, 2nd Edition). 2012. Available online: https:/ /www.mlit.go.jp/crd/ townscape/pdf/koen-shishin01.pdf (accessed on 24 August 2017).

18. Yamada, C.; Terada, T.; Tanaka, T.; Yokohari, M. Directions for Vacant Lot Management in the Outer Suburbs of the Tokyo Metropolitan Region. Urban Reg. Plan. Rev. 2016, 3, 66-84. [CrossRef]

19. Takano, T.; Nakamura, K.; Watanabe, M. Urban residential environments and senior citizens' longevity in megacity areas: The importance of walkable green spaces. J. Epidemiol. Community Health 2002, 56, 913-918. [CrossRef] [PubMed]

20. Gill, S.E.; Handley, J.F.; Ennos, A.R.; Pauleit, S. Adapting cities for climate change: The role of the green infrastructure. Built Environ. 2007, 33, 115-133. [CrossRef]

21. Byrne, J.; Ambrey, C.; Portanger, C.; Lo, A.; Matthews, T.; Baker, D.; Davison, A. Could urban greening mitigate suburban thermal inequity?: The role of residents' dispositions and household practices. Environ. Res. Lett. 2016, 11, 95014. [CrossRef]

22. Kusaka, H.; Hara, M.; Takane, Y. Urban Climate Projection by the WRF Model at 3-km Horizontal Grid Increment: Dynamical Downscaling and Predicting Heat Stress in the 2070's August for Tokyo, Osaka, and Nagoya Metropolises. J. Meteorol. Soc. Jpn. Ser. II 2012, 90, 47-63. [CrossRef]

23. Rupprecht, C.D.D.; Byrne, J.A.; Ueda, H.; Lo, A.Y.H. “It”s real, not fake like a park': Residents' perception and use of informal urban green-space in Brisbane, Australia and Sapporo, Japan. Landsc. Urban Plan. 2015, 143, 205-218. [CrossRef]

24. Rupprecht, C.D.D.; Byrne, J.A. Informal urban green-space: Comparison of quantity and characteristics in Brisbane, Australia and Sapporo, Japan. PLoS ONE 2014, 9, e99784. [CrossRef] [PubMed]

25. Rupprecht, C.D.D.; Byrne, J.A.; Lo, A.Y.H. Memories of vacant lots: How and why residents used informal urban greenspace as children and teenagers in Brisbane, Australia and Sapporo, Japan. Child. Geogr. 2016, 14, 340-355. [CrossRef]

26. Flint, C.G.; Kunze, I.; Muhar, A.; Yoshida, Y.; Penker, M. Exploring empirical typologies of human-nature relationships and linkages to the ecosystem services concept. Landsc. Urban Plan. 2013, 120, 208-217. [CrossRef]

27. Jorgensen, A.; Keenan, R. (Eds.) Urban Wildscapes; Routledge: Abingdon, UK, 2012; ISBN 978-0-415-58106-6.

28. Campo, D. The Accidental Playground; Fordham University Press: New York, NY, USA, 2013.

29. Rupprecht, C.D.D.; Byrne, J.A. Informal urban greenspace: A typology and trilingual systematic review of its role for urban residents and trends in the literature. Urban For. Urban Green. 2014, 13, 597-611. [CrossRef]

30. Informal Urban Greenspace Perception and Use: Survey Instrument. Available online: https://doi.org: 10.13140/RG.2.1.3830.7448 (accessed on 24 August 2017).

31. Takase, Y.; Furuya, K.; Sakuraba, S. The Relationship between Citizens' Willingness to Work for Participation in Green Space Conservation Activities and Attributes, Citizens' Willingness to Work and Attitude toward Participation. J. Jpn. Inst. Landsc. Archit. 2015, 78, 619-624. [CrossRef] 
32. Field, A.; Miles, J.; Field, Z. Discovering Statistics Using R; SAGE: Newcastle upon Tyne, UK, 2012; ISBN 978-1-4462-5846-0.

33. R Development Core Team R: A Language and Environment for Statistical Computing. 2017. Available online: http:/ / www.r-project.org (accessed on 24 August 2017).

34. Bryer, J.; Speerschneider, K.; Bryer, M.J. Package “Likert”. 2016. Available online: http://cran.pau.edu.tr/ web/packages/likert/likert.pdf (accessed on 24 August 2017).

35. Husson, F. Package "FactoMineR". 2017. Available online: https://cran.r-project.org/web/packages/ FactoMineR/FactoMineR.pdf (accessed on 24 August 2017).

36. JASP Team. T. JASP (Version 0.8.1.1). 2017. Available online: https://jasp-stats.org/ (accessed on 24 August 2017).

37. Jamovi Team. T. Jamovi (Version 0.7.5.7). 2017. Available online: https://www.jamovi.org (accessed on 24 August 2017).

38. QGIS Development Team QGIS Geographic Information System; Open Source Geospatial Foundation. 2017. Available online: http:/ / qgis.osgeo.org (accessed on 24 August 2017).

39. Jorgensen, A.; Tylecote, M. Ambivalent landscapes-Wilderness in the urban interstices. Landsc. Res. 2007, 32, 443-462. [CrossRef]

40. Buijs, A.E.; Elands, B.H.M.; Langers, F. No wilderness for immigrants: Cultural differences in images of nature and landscape preferences. Landsc. Urban Plan. 2009, 91, 113-123. [CrossRef]

41. Konijnendijk, C. Between fascination and fear-The impacts of urban wilderness on human health and wellbeing. Socialmed. Tidskr. 2012, 89, 289-295.

42. Mathey, J.; Rink, D. Urban Wastelands-A Chance for Biodiversity in Cities? Ecological Aspects, Social Perceptions andAcceptance of Wilderness by Residents. In Urban Biodiversity and Design; Müller, N., Werner, P., Kelcey, J.G., Eds.; Wiley-Blackwell: Oxford, UK, 2010; pp. 406-424.

43. Rink, D.; Herbst, H. From wasteland to wilderness-Aspects of a new form of urban nature. In Applied Urban Ecology: A Global Framework; Richter, M., Weiland, U., Eds.; Wiley-Blackwell: Chichester, UK, 2011; pp. 82-92.

44. Vicenzotti, V.; Trepl, L. City as Wilderness: The Wilderness Metaphor from Wilhelm Heinrich Riehl to Contemporary Urban Designers. Landsc. Res. 2009, 34, 379-396. [CrossRef]

45. Jeans, D.N. Wilderness, Nature and Society: Contributions to the history of an environmental attitude. Aust. Geogr. Stud. 1983, 21, 170-182. [CrossRef]

46. Head, L.; Muir, P. Suburban life and the boundaries of nature: Resilience and rupture in Australian backyard gardens. Trans. Inst. Br. Geogr. 2006, 31, 505-524. [CrossRef]

47. Instone, L. Encountering Native Grasslands: Matters of Concern in an Urban Park. Aust. Humanit. Rev. 2010, $49,91-117$.

48. Foster, J. Restoration of the Don Valley Brick Works: Whose Restoration? Whose Space? J. Urban Des. 2005, 10, 331-351. [CrossRef]

49. Kowarik, I. Urban wilderness: Supply, demand, and access. Urban For. Urban Green. 2017. [CrossRef]

50. Davis, M. Dead Cities: And Other Tales; New Press: New York, NY, USA, 2002.

51. Kellert, S.R. Attitudes, Knowledge, and Behavior Toward Wildlife Among the Industrial Superpowers: United States, Japan, and Germany. J. Soc. Issues 1993, 49, 53-69. [CrossRef]

52. Corbin, C.I. Vacancy and the Landscape: Cultural Context and Design Response. Landsc. J. 2003, $22,12-24$. [CrossRef]

53. Franck, K.A.; Stevens, Q. (Eds.) Loose Space: Possibility and Diversity in Urban Life; Routledge: Abingdon, UK, 2007.

54. Schneekloth, L. Unruly and Robust: An abandoned industrial river. In Loose Space: Possibility and Diversity in Urban Life; Franck, K.A., Stevens, Q., Eds.; Routledge: Abingdon, UK, 2007; pp. 253-270.

55. Unt, A.-L.; Travlou, P.; Bell, S. Blank Space: Exploring the Sublime Qualities of Urban Wilderness at the Former Fishing Harbour in Tallinn, Estonia. Landsc. Res. 2013, 39, 267-286. [CrossRef]

56. Wolch, J.R.; Byrne, J.; Newell, J.P. Urban green space, public health, and environmental justice: The challenge of making cities "just green enough". Landsc. Urban Plan. 2014, 125, 234-244. [CrossRef]

57. Cabinet Office Japan. Kokumin Seikatsu ni Kansuru Yoron Chōsa (In Japanese; Public Opinion Poll on the Public's Everyday Life). Available online: http:/ / survey.gov-online.go.jp/h26/h26-life/index.html (accessed on 19 June 2017). 
58. Guidelines for Discovery and Use of Land in Cases of Unclear Ownership. Available online: http: / / www.webcitation.org/ query?url=http\%3A\%2F\%2Fwww.mlit.go.jp\%2Fcommon\%2F001178691. pdf\&date=2017-08-24 (accessed on 24 August 2017).

59. Rahmann, H.; Jonas, M. Void Potential: Spatial Dynamics and Cultural Manifestations of Residual Spaces. In Terrain Vague: Interstices at the Edge of the Pale; Mariani, M., Barron, P., Eds.; Routledge: Abingdon, UK, 2013; pp. 89-104.

60. Sorensen, A. Conflict, consensus or consent: Implications of Japanese land readjustment practice for developing countries. Habitat Int. 2000, 24, 51-73. [CrossRef]

61. Funabiki, T. A Study on the Relations between Land Use Regulation and Public Compensation in the Methods of Green-space Acquisition and Enhancement System. Pap. Environ. Inf. Sci. 2009, 23, 13-18. [CrossRef]

62. Rupprecht, C.D.D.; Byrne, J.A.; Garden, J.G.; Hero, J.-M. Informal urban green space: A trilingual systematic review of its role for biodiversity and trends in the literature. Urban For. Urban Green. 2015, 14, 883-908. [CrossRef]

63. Bonthoux, S.; Brun, M.; di Pietro, F.; Greulich, S.; Bouché-Pillon, S. How can wastelands promote biodiversity in cities? A review. Landsc. Urban Plan. 2014, 132, 79-88. [CrossRef]

64. Oswalt, P.; Overmeyer, K.; Misselwitz, P. Patterns of the Unplanned. In Pop Up City; Schwarz, T., Rugare, S., Eds.; Cleveland Urban Design Collaborative: Cleveland, OH, USA, 2009; pp. 5-18.

65. Explosives. Dumping Refuse on Vacant Lots. Injury to Children. Travell v. Bannerman, 75 N.Y. Supp. 866. Yale Law J. 1902, 12, 47. [CrossRef]

66. Arnstein, S.R. A Ladder Of Citizen Participation. J. Am. Inst. Plann. 1969, 35, 216-224. [CrossRef]

67. Takase, Y.; Furuya, K. Issues in Promoting Participation in Open Space Conservation Activities and Priority Ranking of Solutions from University Students' Perspectives. J. Jpn. Inst. Landsc. Archit. 2013, 76, 717-722. [CrossRef]

68. Takase, Y.; Furuya, K.; Sakuraba, S. Promotion Process for Green Space Conservation Activity Participation from Residents' Perspectives. J. Archit. Plan. Trans. AIJ 2014, 79, 2241-2249. [CrossRef]

69. Takase, Y.; Furuya, K.; Sakuraba, S. Challenges to Promote Participation in Conservation Activities Based on differences of attitude between Citizens and Open space Conservation Activity Organizations. J. Jpn. Inst. Landsc. Archit. 2014, 77, 553-558. [CrossRef]

70. Takase, Y.; Furuya, K. Study on promoting public participation in green space conservation activities run by local governments. J. City Plan. Inst. Jpn. 2016, 51, 1016-1023. [CrossRef]

71. Qviström, M. Taming the wild: Gyllin's Garden and the urbanization of a wildscape. In Urban Wildscapes; Jorgensen, A., Keenan, R., Eds.; Routledge: Abingdon, UK, 2012; pp. 187-200.

72. Sorensen, A. Centralization, urban planning governance, and citizen participation in Japan. In Cities, Autonomy, and Decentralization in Japan; Hein, C., Pelletier, P., Eds.; Routledge: Abingdon, UK, 2006; pp. 101-127.

73. DelSesto, M. Cities, Gardening, and Urban Citizenship: Transforming Vacant Acres into Community Resources. Cities Environ. CATE 2015, 8, 3.

74. Rosol, M. Grassroots Gardening Initiatives: Community Gardens in Berlin. In Enterprising Communities: Grassroots Sustainability Innovations; Robertson, D.P., Ed.; Emerald Group Publishing Limited: Bingley, UK, 2012; pp. 123-143.

75. Chan, J.; DuBois, B.; Tidball, K.G. Refuges of local resilience: Community gardens in post-Sandy New York City. Urban For. Urban Green. 2015, 14, 625-635. [CrossRef]

76. Rupprecht, C.D.D.; Byrne, J.A. Informal urban green space as anti-gentrification strategy? In Just Green Enough: Urban Development and Environmental Gentrification; Routledge Equity, Justice and the Sustainable City; Curran, W., Hamilton, T., Eds.; Routledge: London, UK, 2017.

77. Curran, W.; Hamilton, T. Just green enough: Contesting environmental gentrification in Greenpoint, Brooklyn. Local Environ. 2012, 17, 1027-1042. [CrossRef]

(C) 2017 by the author. Licensee MDPI, Basel, Switzerland. This article is an open access article distributed under the terms and conditions of the Creative Commons Attribution (CC BY) license (http:/ / creativecommons.org/licenses/by/4.0/). 